\title{
An Electron Microscopic Study of the Kitten Liver with Special Reference to Fat-Storing Cells
}

\author{
Yutaka Tanuma, Masako Ohata and Toshio Ito \\ Department of Anatomy (Frof. K. Uchida and Prof. T. Iто), Teikyo University School of Medicine, \\ Tokyo, Japan
}

Received May 19, 1980

\begin{abstract}
Summary. In a 67-day-old female kitten, the morphological differentiation of the hepatic parenchyma has been electron microscopically examined. 1) In spite of the advanced ultrastructural differentiation of the hepatocyte, the usual location of the Golgi complex to the apical cytoplasm around the bile canaliculus has not yet been established. Numerous mitochondria are mingled with round microbodies characterized by a marginal plate and a crystalloid core. Tubular cisternae of the SER occur only around the microbodies and lack within the accumulation of glycogen $a$-particles. 2) The sinusoidal lining has been fully differentiated and is composed of the "cytoplasmic processes" and the "sieve plates" whose fenestrae average $1300 \AA$ in diameter. 3) Kupffer cell shows an active phagocytosis to blood cells. The fuzzy coat is unsatisfactorily preserved. The cytoplasm occasionally shows short segments of a worm-like body. 4) The fat-storing cell (FSC) contains a small amount of lipid droplets which mostly appear with in the dense accumulation of glycogen $\beta$-particles. Also empty FSCs devoid of lipid droplets mostly possess glycogen accumulations. The glycogen accumulations enclosing lipid droplets are closely juxtaposed by cisternae of the RER and mitochondria, suggesting the possible involvement of these organelles as well as glycogen in the lipid synthesis in the FSC. In most FSCs, abundant cisternae of the RER are dilated and filled up with a finely flocculent material, suggesting an active production of collagen precursor. The FSCs possess abundant microfilaments and microtubules. A single cilium is issued into the Disse's space from one of the paired centrioles located in the Golgi area. 5) The Disse's space of the kitten contains, besides FSCs, plasma cells and macrophages. The latter agree in ultrastructure with the Kupffer cells and are assumed to be transformed into them by being incorporated in the endothelial lining of the sinusoid.
\end{abstract}

In spite of numerous studies on the fine structure of the liver of adult animals, light and electron microscopic observations of the hepatic parenchyma in immature animals are limited. The present electron microscopic study has been carried out in the liver from a 67-day-old female cat with some ultrastructural findings obtained concerning the hepatic parenchyma especially the fat-storing cell and other sinusoidal cells. 


\section{MATERIAL AND METHOD}

A 67-day-old female cat fed with solid food coated with fish paste was used. It was anesthetised by a mixture of $\alpha$-chloralose and urethane. After laparotomy, the liver was fixed by perfusion through the portal vein with a cold fixative containing a $2.5 \%$ glutaraldehyde and a $0.1 \mathrm{M}$ phosphate buffer at $\mathrm{pH} 7.4,0^{\circ} \mathrm{C}$. After perfusion, the liver was excised and thin slices of tissue were cut, under a drop of the fixative, into minute blocks. After $2 \mathrm{hr}$ of fixation, the blocks were rinsed several times in a cold $0.1 \mathrm{M}$ phosphate buffer containing $5 \%$ sucrose at $\mathrm{pH} 7.4$ and left overnight in the same buffer at $5^{\circ} \mathrm{C}$. They were postfixed for $90 \mathrm{~min}$ by immersion in a $1 \% \mathrm{OsO}_{4}$ solution in a $0.1 \mathrm{M}$ phosphate buffer $(\mathrm{pH} 7.4)$ at $0^{\circ} \mathrm{C}$. Following dehydration in graded ethanol, tissues were embedded in Epon 812 and sectioned on a Porter-Blum Ultra-Microtome MT2-B. Ultrathin sections were stained with saturated uranyl acetate and Sato's lead solution. Micrographs were taken with a JEM-100C electron microscope.

\section{RESULTS}

\section{Hepatocyte}

The hepatocyte is characterized by an abundance of mitochondria and glycogen $\alpha$ particles distributed throughout the cytoplasm (Fig. 1) except in the narrow perinuclear cytoplasm and the apical ectoplasmic layer bordering the intercellular bile capillary. Mitochondria appear round, oval or elongated in profile with an electron dense matrix and rather irregularly oriented cristae. Intramitochondrial granules are not infrequent. Glycogen $\alpha$-granules are densely grouped in areas of variable sizes from which other organelles are excluded. Flattened cisternae of the rough endoplasmic reticulum (RER) accompanied by free polysomes form more or less conspicuous groups, in which some of the cisterns are elongated along the surface of mitochondria. Cisternae of the smooth endoplasmic reticulum (SER) are difficult to identify. They are not found within the dense accumulations of the glycogen particles. Tubular cisternae of the SER are marked around microbodies; they are often closely applied to the limiting membrane of the microbody (Fig. 2a, b). The Golgi complex is composed of stacks of flattened cisternae and small vesicles. The cisternae are dilated into irregularly shaped vacuoles at random sites and at the ends. The very low density lipoprotein (VLDL) particles in the Golgi cisternae are not conspicuous. The location of the Golgi complex is variable; it is frequently found close to the nucleus, but occasionally in the peripheral cytoplasm close to the perisinusoidal surface. Small spherical dense bodies, probably lysosomes, are frequently found in the vicinity of the Golgi complex; they are homogeneously electron-dense and often contain small vacuoles, but they never show a complex heterogeneous structure such as lipofuscin granules. Among the mitochondria there occur a considerable number of microbodies or peroxisomes which are almost round in shape and limited by a single membrane, about $0.4-0.7 \mu \mathrm{m}$ in diameter and which appear somewhat electronlucent as compared with the mitochondria (Fig. 2a, b). They are characterized by 


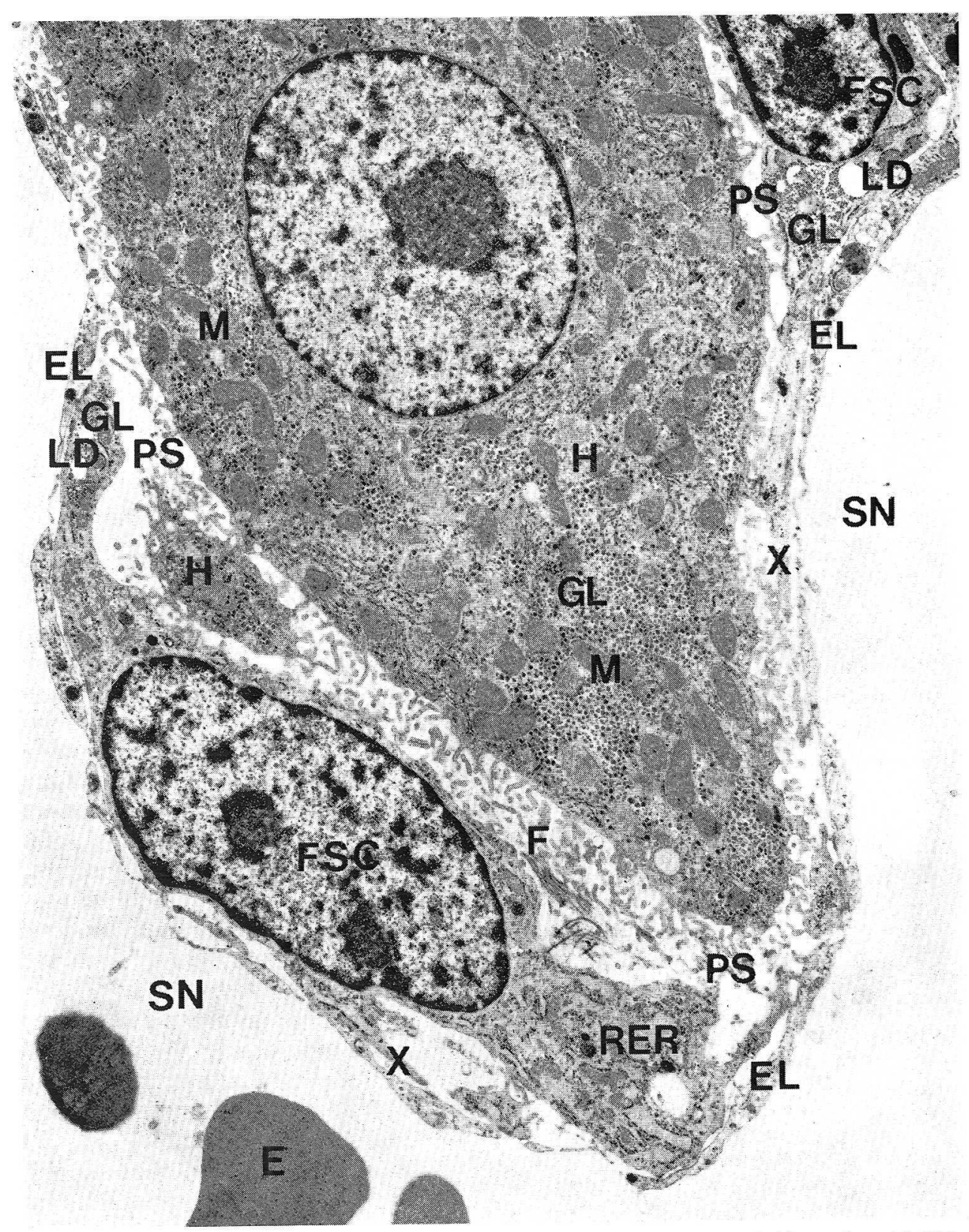

Fig. 1. Survey picture of a small portion of the hepatic parenchyma surrounded by a sinusoid (SN). Between the hepatocyte $(H)$ filled with mitochondria $(M)$ and glycogen particles $(G L)$ and the sinusoidal endothelial lining $(E L)$, intervenes the perisinusoidal space of Disse $(P S)$ in which two fat-storing cells $(F S C)$ and collagen fiber $(F)$ are seen. Fat-storing cells enclose numerous cisternae of the rough endoplasmic reticulum $(R E R)$ and glycogen accumulation $(G L)$ which contains lipid vacuoles $(L D)$. E erythrocyte, $X$ subendothelial processes of FSC $\times 8,900$ 


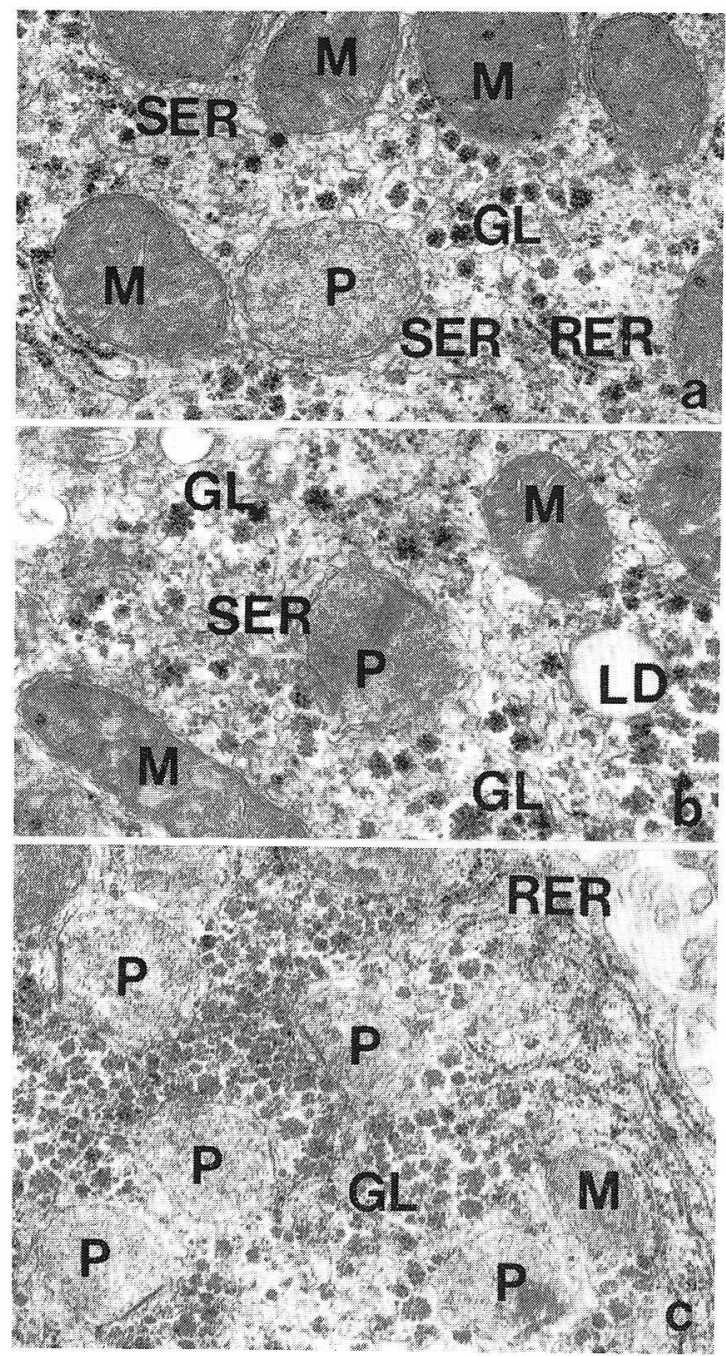

Fig. 2. a-c. Peroxisomes $(P)$, mitochondria $(M)$, smooth $(S E R)$ and rouph endoplasmic reticulum (RER) and glycogen $\alpha$-particles $(G L)$ in the hepatocyte. a. Intimate spatial relation between tubular SER and peroxisome is noticed. $\times 25,000$. b. Intimate spatial relation is shown between peroxisome $(P)$ with a marginal plate and a crystalloid core and tubular SER. LD lipid droplet. $\times 25,000$. c. Cluster of peroxisomes provided with a marginal plate in the accumulation of glycogen $\alpha$-particles. $\times 20,000$ an electron-dense marginal plate and an irregularly shaped nucleoid or a core with a crystalline appearance (Fig. 2b, c). They often make small groups and show an intimate spatial relation to the accumulation of glycogen particles (Fig. 2c).

Small lipid droplets are occasionally scattered in the cytoplasm, but large ones are very rare. Regardless of their size, they are usually accompanied by an accumulation of glycogen $\alpha$-granules which are closely attached to the surface of the lipid droplets.

The apical surface of the hepatocyte borders the intercellular bile canaliculus, protruding sparse short fungiform microvilli into the lumen. The basal surface facing the perisinusoidal or Disse's space is provided with abundant, slender microvilli which, bifurcating and twisted, form a meshwork across the space. The basal lamina is lacking. Along the basal surface of the kitten hepatocyte relatively numerous bristle-coated invaginations (caveolae) and vesicles are observed, suggesting a vigorous pinocytotic activity. Smooth-surfaced caveolae and vesicles are sparse; they are larger than the bristle-coated ones and occasionally contain a few electron-dense particles.

The narrow intercellular space between the adjacent hepatocytes opens into the perisinusoidal space. The opening site is more or less widened to receive microvilli from the bordering hepatocytes and is designated as the recessus. Abutting on the intercellular bile canalicule the apposed hepatocytes are connected by the junctional complex. Desmosomes and gap junctions occasionally occur in the nar- 
rowed portion of the intercellular space between the recessus and the junctional complex.

Disturbed by rich organelles and inclusions, microtubules in hepatocyte cytoplasm are only occasionally detectable. Microfilaments are easily found in the ectoplasmic layers, bordering the entire cell surface.

\section{Sinusoidal endothelial cell}

The sinusoidal endothelium is composed of the perikaryon containing an elongated nucleus and the membranous cytoplasmic extensions. Cell organelles are mostly distributed in the narrow perikaryonal cytoplasm; while the Golgi complex composed of flattened cisternae and vesicles with an occasional centriole is found in the vicinity of one pole of the nucleus (Fig. 3). A few mitochondria as those of small as fatstoring cells are randomly distributed.

There are a moderate number of cisternae of the RER while free polysomes are relatively numerous and distributed throughout the cytoplasm. Some relatively large dense bodies, probably lysosomes, with variable electron densities and phagosome-like vacuoles occur in a considerable number, and multivesicular bodies are

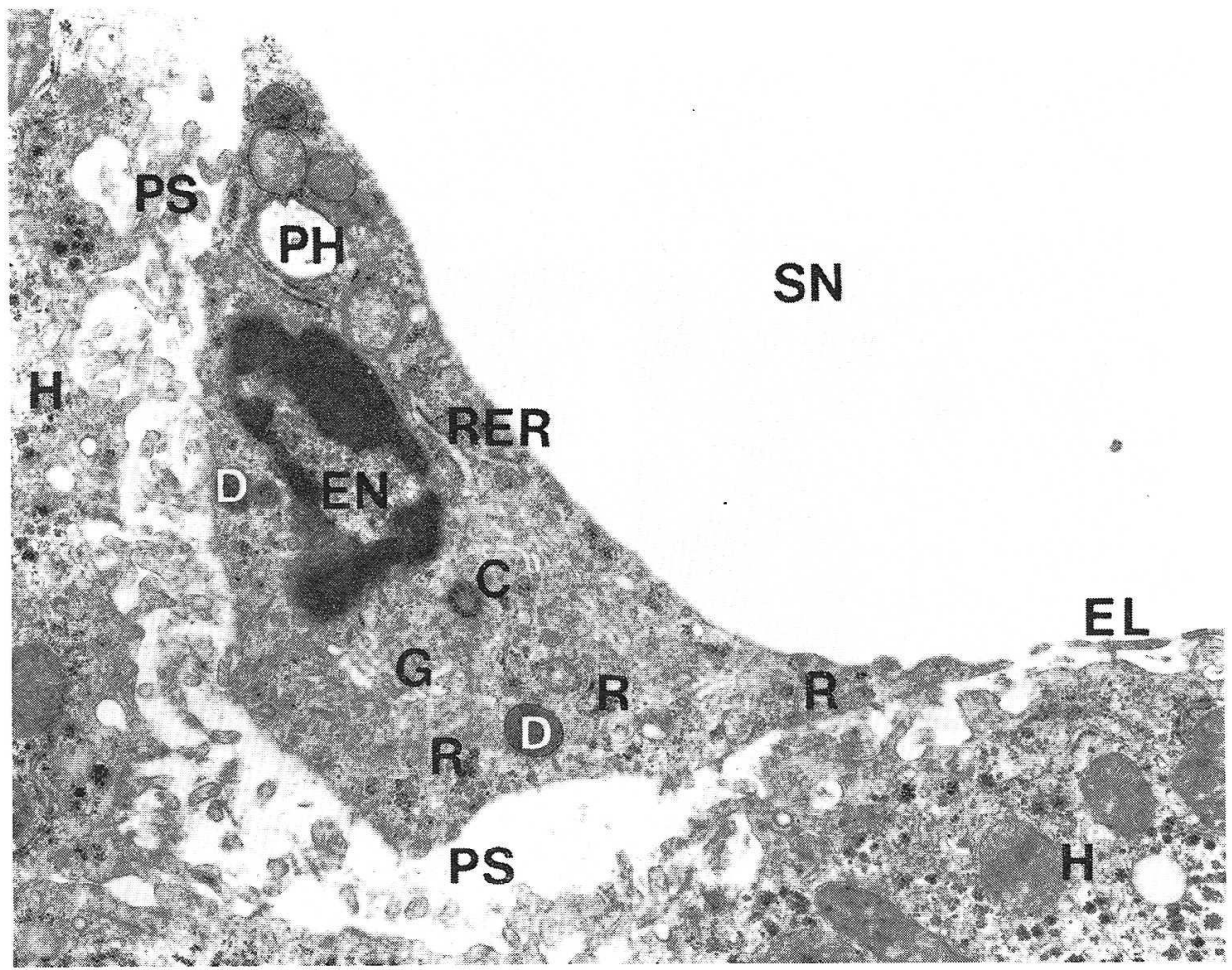

Fig. 3. Perikaryon of an endothelial cell $(E N)$. On one side of the nucleus Golgi complex $(G)$ containing a centriole $(C)$ is present. Also seen are lysosomes $(D)$, phagosome-like vacuoles $(P H)$, flattened cisternae of the RER and many free ribosomes $(R)$. The perikaryon extends into the attenuated sieve plates of the endothelial lining $(E L) . \quad H$ hepatocyte, $P S$ perisinusoidal space, $S N$ sinusoid. $\times 15,000$ 


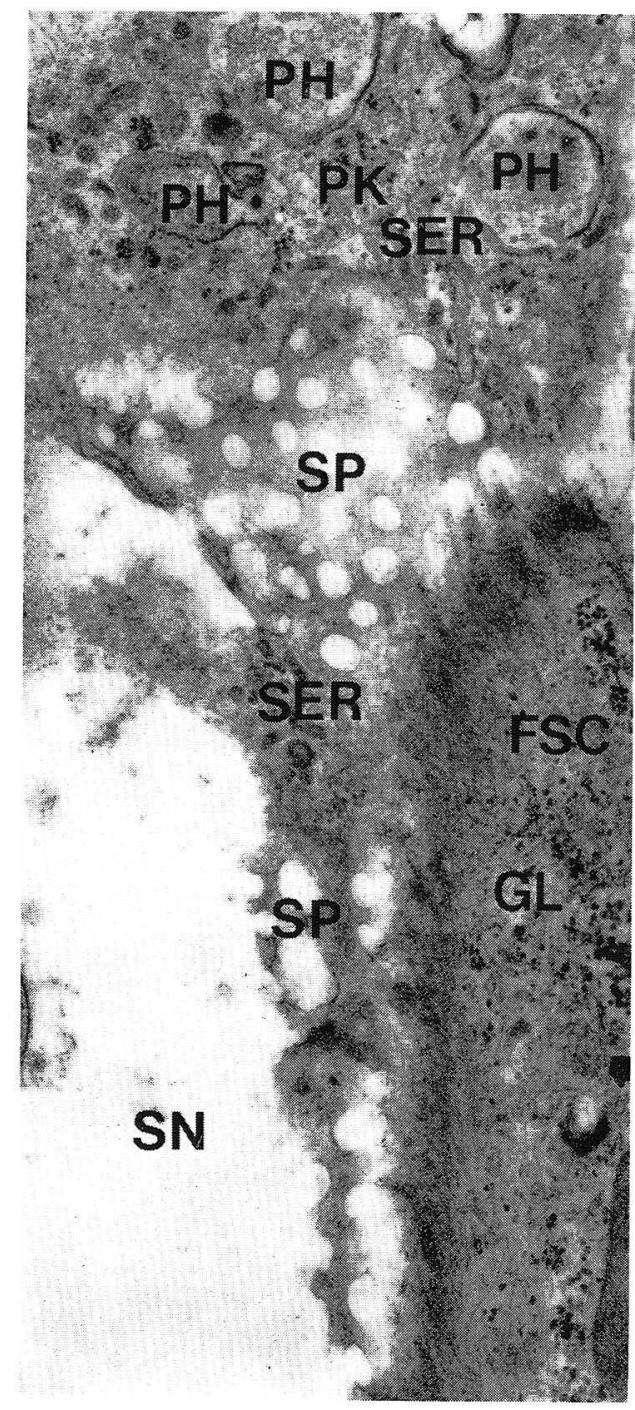

Fig. 4. Tangential section of sieve plates $(S P)$ of the sinusoidal endothelium. The perikaryon $(P K)$ contains tubular SER filled with dense materials and phagosomes $(P H)$. On the right side of the endothelial lining is seen a part of a fat-storing cell (FSC) containing glycogen $\beta$-particles $(G L)$, many microfilaments and microtubules. $S N$ sinusoid. $\times 25,000$ occasionally found among them. In addition, there occur, in most cells, numerous profiles of smooth membrane-bound tubules containing an electron-dense material. These organelles suggest the phagocytic activity of the sinusoidal endothelium. Some microtubules and microfilaments are observed running in random directions. Bristle-coated invaginations and vesicles are detected along the plasma membrane. As clarified by WIsse (1970), the cytoplasmic sheet is divided into two parts: the "cytoplasmic processes" and the "sieve plates." In the former the cytoplasm is considerably thick, whereas in the latter it is as thin as $500 \AA$ on the average. These two parts are alternately distributed, although their individual extent is widely variable from place to place. The cytoplasmic processes contain all the cell organelles found in the perikaryon except the Golgi complex. Microtubules and microfilaments are oriented parallel to the long axis of the processes. Neighboring endothelial cells are joined at the ends of their cytoplasmic processes. Their closely apposed plasma membranes are connected by an electron dense material. The cytoplasm close to the plasma membranes also exhibits increased electron density (Fig. 10). The same mode of junction between sinusoidal endothelial cells has been designated by WISSE (1970) as the "junctional complex." The sieve plates consist of clusters of round fenestrae or pores of variable numbers. Their dimeters range from 800 to $2,000 \AA$ with an average of $1,300 \mathrm{~A}$ (Fig. 4). Intervals between individual pores do not range so widely.

\section{Kupffer cell}

The Kupffer cell is a cytoplasm-rich polymorphic cell and its bulky body bulges into the sinusoidal lumen. In some instances the cell body appears to lie on 
the fenestrated endothelial lining (Fig. 6, 10), but in others, it appears to cover a large gap of the endothelial sheet (Fig. 5). In the latter case, the Kupffer cell immediately borders on the perisinusoidal space to compensate the endothelial gap and to maintain the integrity of the endothelial lining. In this case, the margins of the endothelial processes and the Kupffer cell are connected by junctions, which are structurally identical with the so-called "junctional complex" (W ISSE, 1970) between the endothelial cells (Fig. 5). From its sinusoidal surface, Kupffer cell projects many cytoplasmic processes of variable configurations which probably correspond to pseudopods. Slender ones are filopodia and occasionally reach the opposite wall of the sinusoid. Filopodial processes of neighboring Kupffer cells sometimes interdigitate. Unlike the endothelial cell the Kupffer cell never issues the fenestrated membranous cytoplasm (WISSE, 1972). Besides extending processes into the sinusoid, it projects sparse short processes from its perisinusoidal surface into the Disse's space (Fig. 5, 7). The Kupffer cell is further differentiated from the endothelial cell by the so-called "fuzzy coat" (glycocalyx) which covers its entire surface including the processes. In the specimens prepared by perfusion fixation with glutaraldehyde followed by immersion fixation with osmic acid, this delicate surface structure, as pointed out by WISSE (1972), is preserved only unsatisfactorily (Fig. 5, 9, 10). Yet the remainder of this structure suffices for the distinction of the Kupffer cell from the endothelial cell.

The Kupffer cell is characterized by numerous dense bodies, probable lysosomes, of variable sizes which often make clusters (Fig. 6). In addition, the cell frequently has large vacuoles, probable phagosomes, which often contain finely flocculent materials, residues of digested cell components, an ingested erythrocyte, granulocyte and occasional blood platelet (Fig. 6,7,9). Especially in the Kupffer cell of the kit-

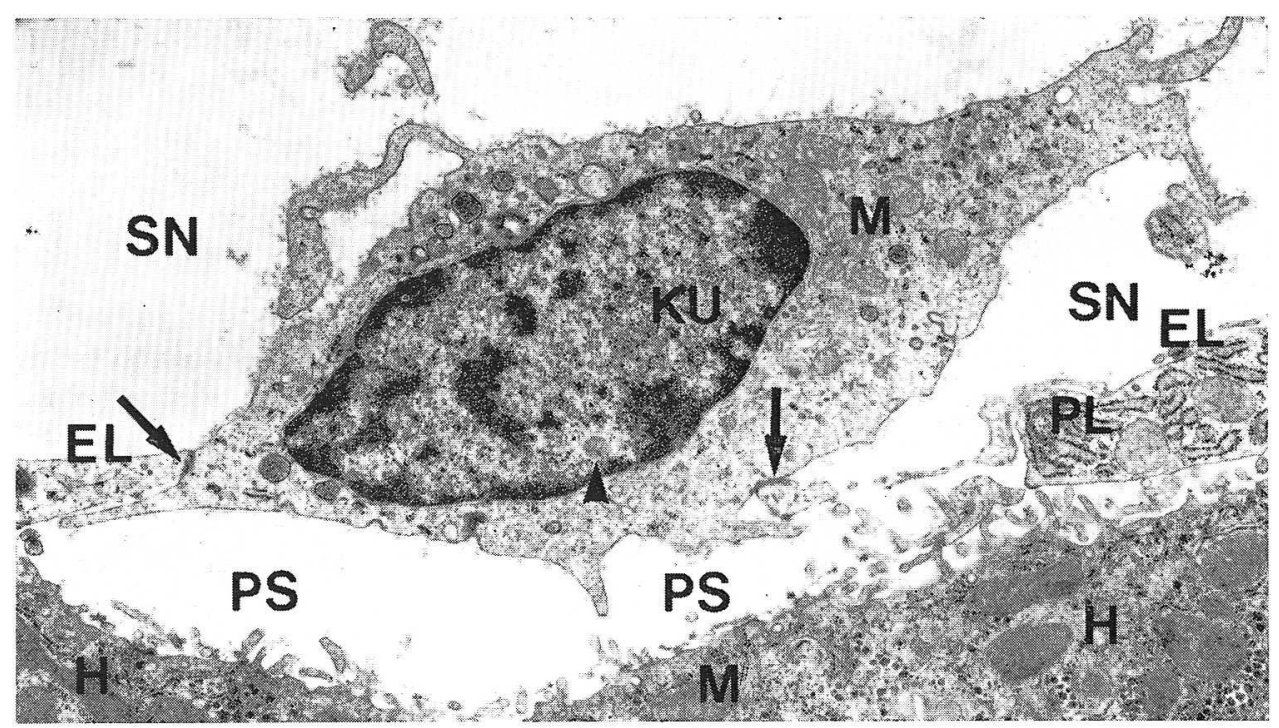

Fig. 5. A Kupffer cell $(K U)$ incorporated in the sinusoidal endothelial lining $(E L)$ by means of junctions (arrows); the perisinusoidal surface of the Kupffer cell covers large gap in the endothelial lining, sending out three microvillous processes into the Disse's space (PS). $H$ hepatocyte, $M$ mitochondria, $P L$ plasma cell in the Disse's space, $S N$ sinusoid. Arrowhead indicates a spheridy. $\times 10,000$ 


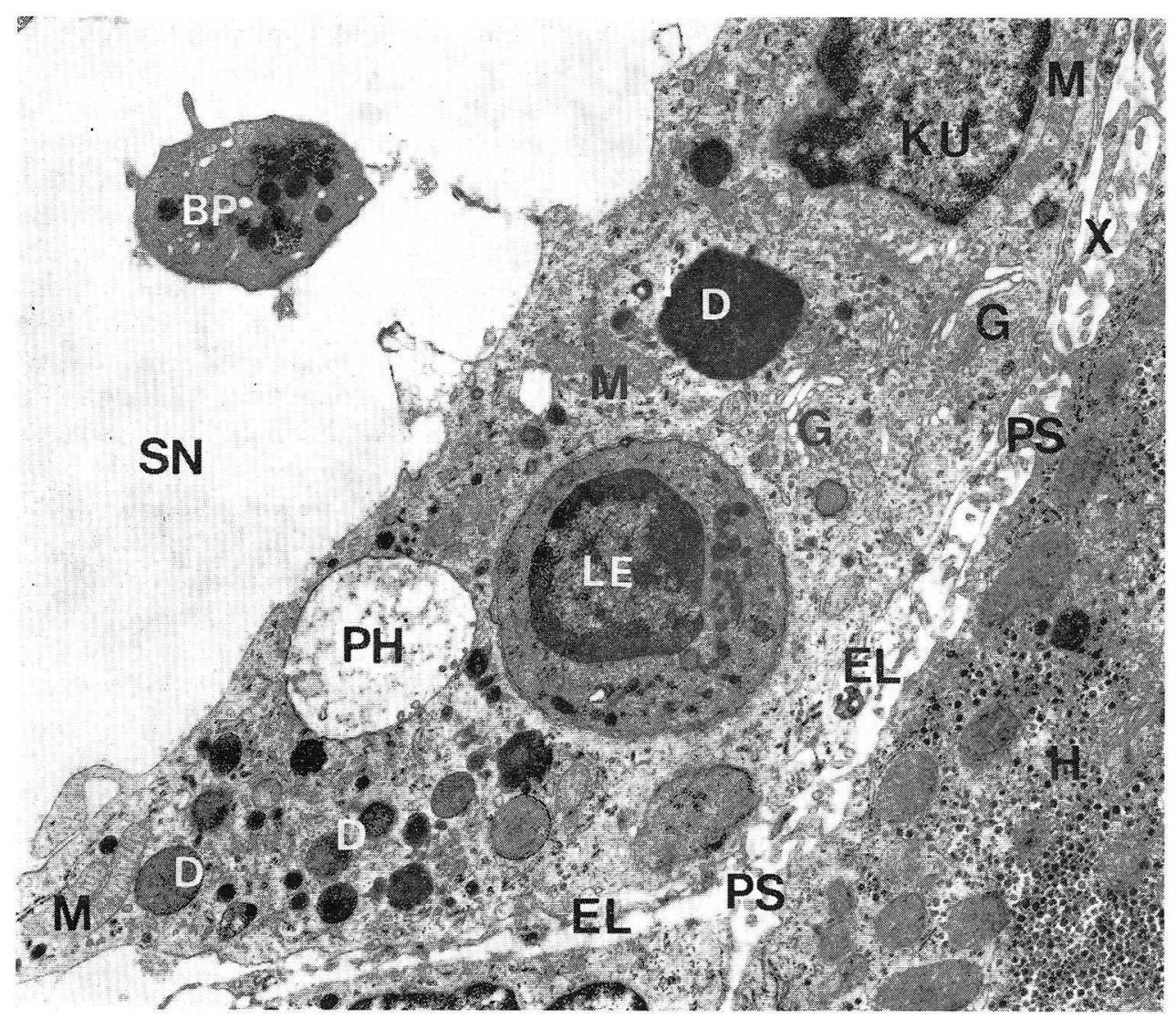

Fig. 6. A Kupffer cell $(K U)$ containing large Golgi complex $(G)$, mitochondria $(M)$, numerous lysosomes $(D)$ of variable sizes and phagosomes $(P H)$, one of which contains a granulocyte $(L E)$. $\quad B P$ blood platelet in sinusoid $(S N), E L$ endothelial lining, $H$ hepatocyte, $P S$ perisinusoidal space, $X$ subendothelial process of FSC. $\quad \times 10,000$

ten, more than two blood cells may be occasionally ingested, suggesting an active phagocytic activity. As seen in the endothelial cells, many profiles of smooth membrane-bound tubules containing an electron-dense material are also found throughout the cytoplasm even in the dense body clusters. Close to the nucleus a large Golgi complex is found, being composed of stacks of flattened and or dilated cisterns and vesicles: among the vesicles larger vesicles containing an electron-dense core are often seen (Fig. 6). Round, oval and occasionally elongated profiles of mitochondria are dispersed in the cytoplasm, occasionally forming groups. They are somewhat larger than those of the endothelial cell, but distinctly smaller than those of the hepatocyte. The cristae are regularly arranged (Fig. 6, 9). Flattened cisternae of the RER and free polysomes are distributed throughout the cytoplasm. Along the plasma membrane are seen sparse bristle-coated invaginations and vesicles which are larger than those found among the Golgi vesicles. The cytoplasmic matrix contains abundant microfilaments among which are detected sparse microtubules running in random directions. Short segments (about 1,100 A in diameter) of the worm- 


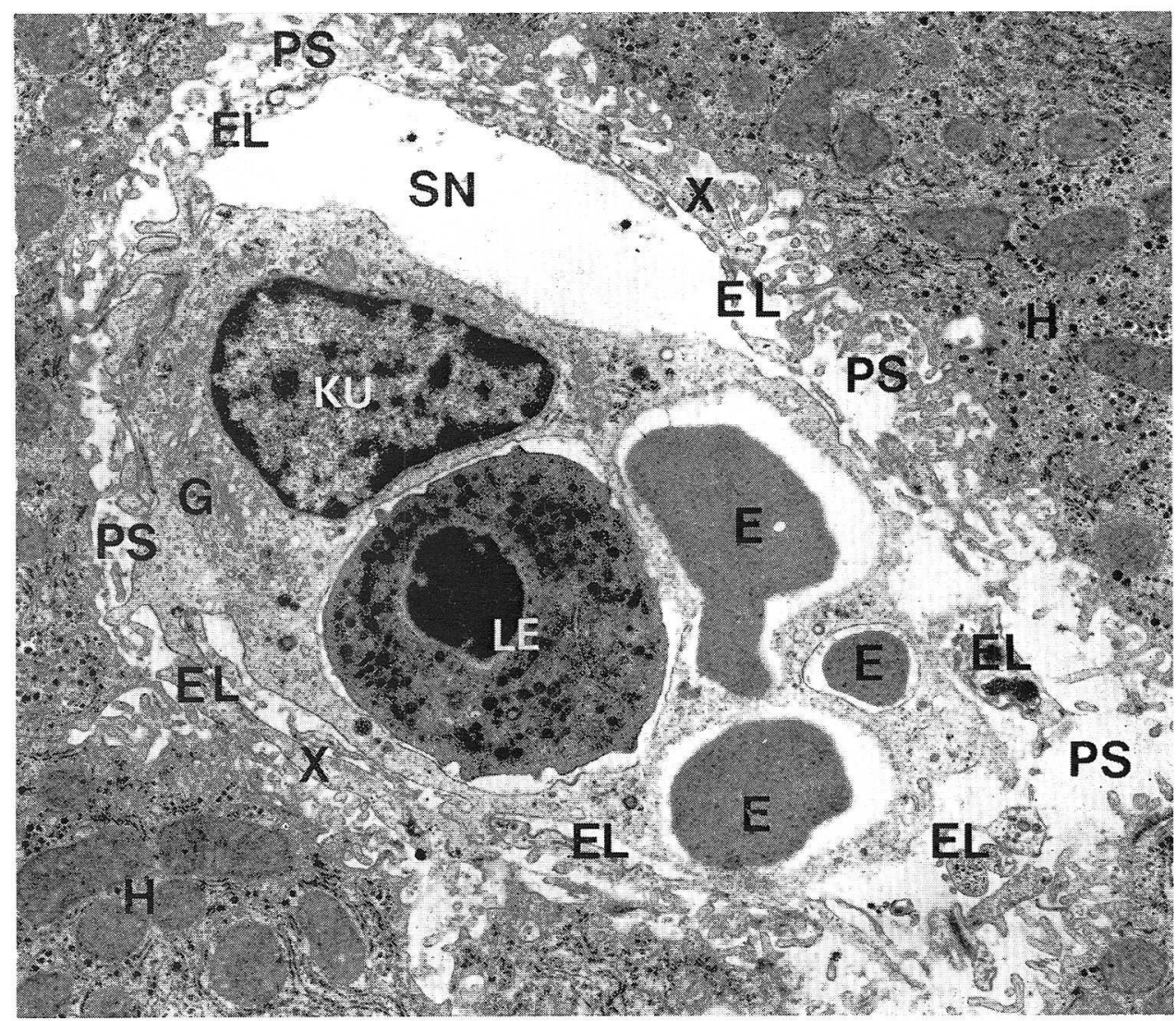

Fig. 7. A Kupffer cell $(K U)$ ingesting three erythrocytes $(E)$ and one granulocyte $(L E)$ in the phagosomes. It protrudes several cytoplasmic processes (pseudopods) into the Disse's space $(P S)$. EL endothelial lining, $G$ Golgi complex, $H$ hepatocytes, $S N$ sinusoid, $X$ subendothelial processes of FSC. $\times 10,000$

like structure, or micropinocytosis vermiformis, are found only rarely in the Kupffer cell of the kitten (Fig. 8a,b). Deep canal-like indentations (about 1,100 $\AA$ in diameter) of the plasma membrane present the appearance of the worm-like structure (Fig. 9). The Kupffer cell nucleus sometimes contains one or two round spheridies (nuclear bodies); they are composed of a fibrillar material, surrounded by an electron transparent halo (Fig. 5, 10). The endothelial cell nucleus may also possess it, though less frequently.

\section{Fat-storing cell (FSC, Ito cell)}

The FSC is located in the perisinusoidal or Disse's space, being separated, in contrast to the Kupffer cell, by the endothelial lining from the sinusoidal lumen (Fig. 1), and accompanied by abundant hepatocytic microvilli. In the immature kitten, FSCs are clearly identified by its known morphological characteristics, although empty ones devoid of lipid droplets are not rare. The FSC possesses no basal lamina and contains large amounts of cisternae of the RER and free polysomes distributed 


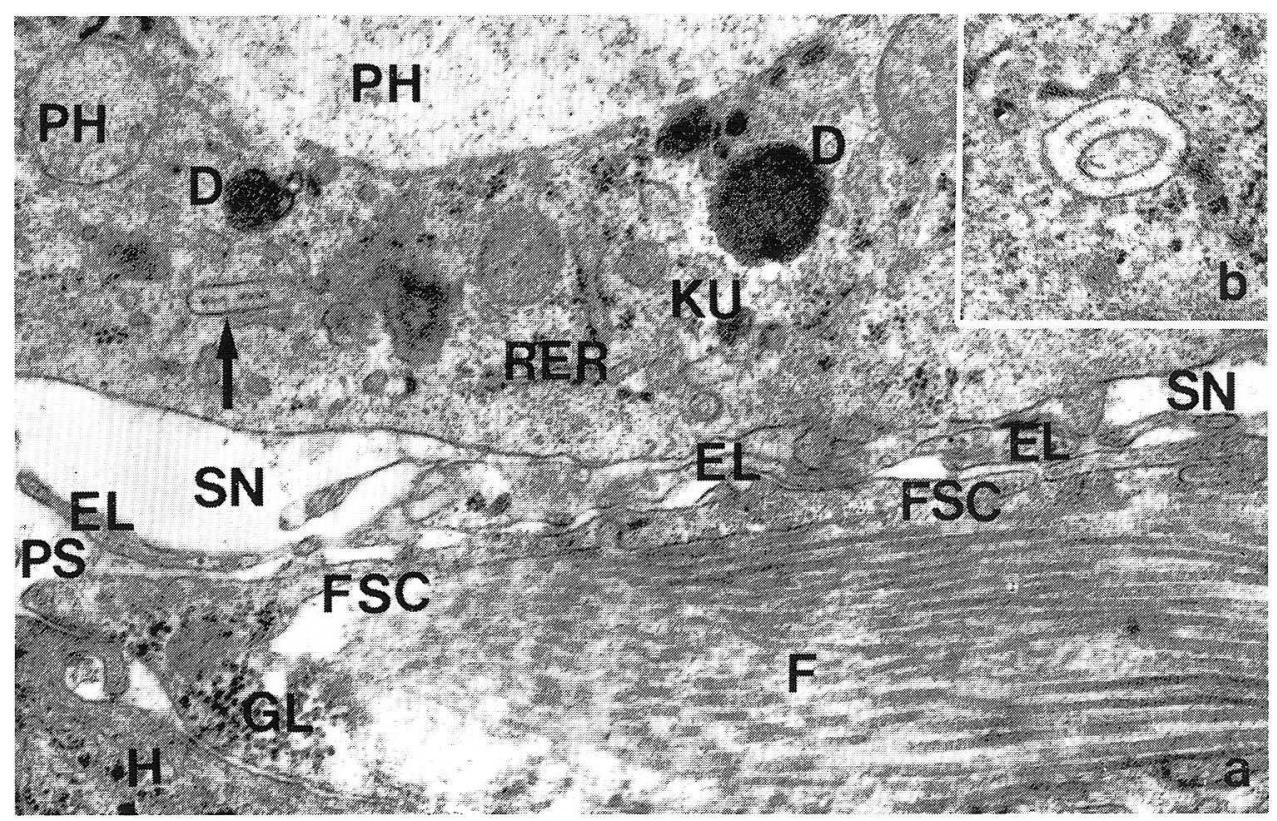

Fig. 8. a. A small part of a Kupffer cell $(K U)$ in the sinusoid ( $S N)$ containing a short segment of the worm-like body characterized by a median dense line (arrow). A thick bundle $(F)$ of collagen fibrils (270-460 $\hat{\mathrm{A}}$ in diameter) run in the perisinusoidal space $(P S)$. Along the bundle, a cytoplasmic process of the fat-storing cell $(F S C)$ is extended, with an accumulation of glycogen $\beta$-particles $(G L)$ in its end part. $D$ lysosome, $E L$ endothelial lining, $H$ hepatocyte, $P H$ phagosome. $\times 25,000$. b. A circular segment of the worm-like body. $\times 32,500$

throughout the entire cytoplasm except the Golgi area (Fig. 1). The fine structure of the nucleus resembles that of the sinusoidal endothelium and possesses one or two nucleoli and an occasional spheridy surrounded by an electron-lucent halo. The cytoplasm/nuclear ratio is generally small. On one side of the nucleus there occurs a relatively large Golgi complex composed of stacks of flattened cisterns with dilated portions and many vesicles mingled with some coated ones (Fig. 15). A few small vacuoles or larger vesicles containing an electron-dense core are occasionally found. Within the Golgi area a diplosome is not rarely detected (Fig. 11). From one of the paired centrioles a single cilium may be sent out into a deep invagination of the plasma membrane extended to the diplosome (Fig. 12b). The FSC is relatively rich in microfilaments and microtubules which run in random directions in the cell body but are concentrated in the subsurface layer, oriented in parallel to the cell surface. The microtubules tend to converge to the diplosome from which they inversely show irregular radiation toward all directions (Fig. 11). Mitochondria as small as those of the endothelial cell are round, oval, rod-shaped and occasionally filamentous in profile and distributed among the closely arranged cisterns of the RER. In the kitten liver, most of the cisterns of the RER are more or less strikingly dilated, showing multiple configurations and are densely fllled with fuzzy fibrillar or flocculent material of moderate electron density, which probably represent precollagen (Fig. 1, 11, 12a, 13). This finding seems to suggest that an active fibrogenesis may proceed in the kitten 


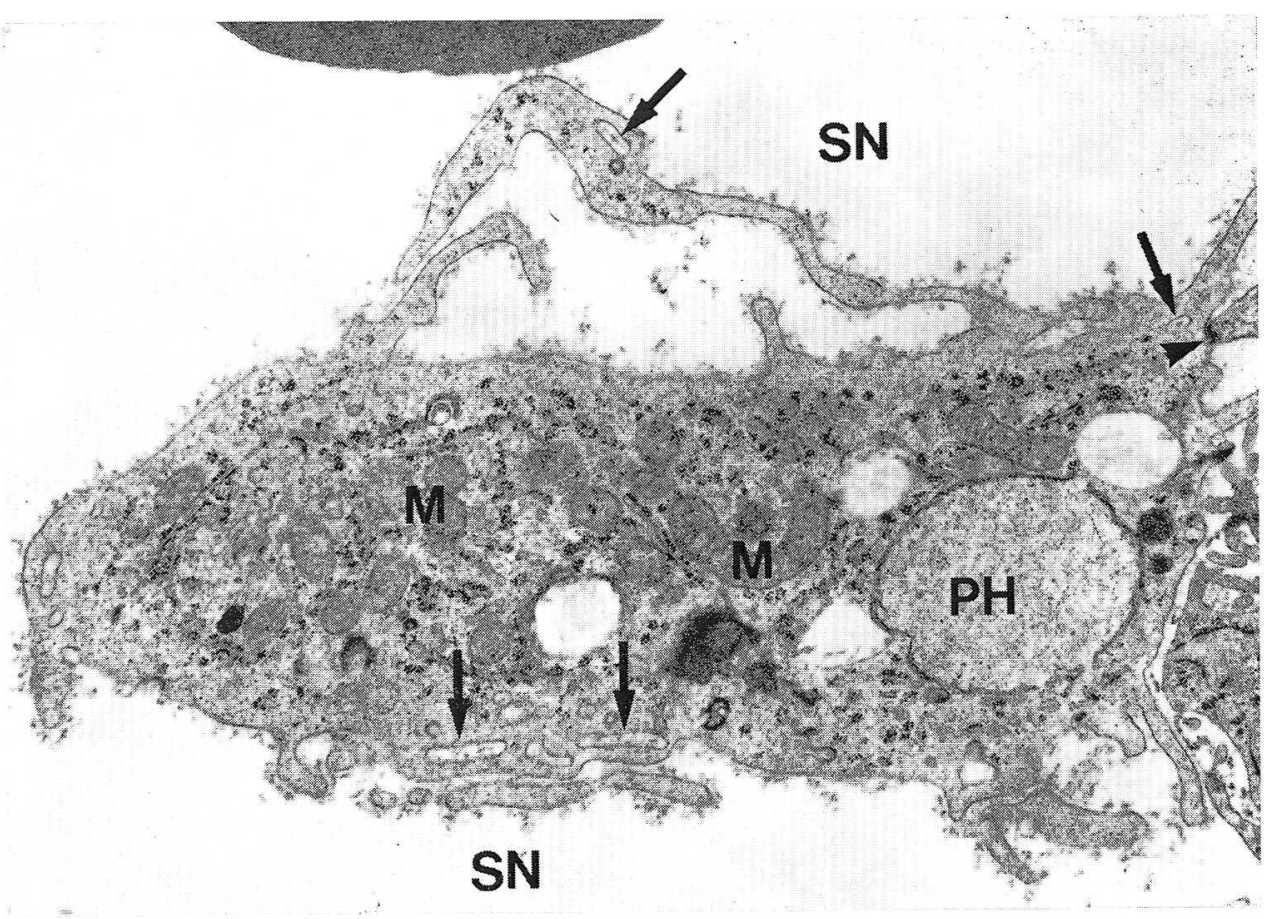

Fig. 9. A Kupffer cell possessing several segments of the worm-like body (arrows), probably formed by deep indentations of the plasma membrane. $M$ mitochondria, $P H$ phagosome, $S N$ sinusoid. The arrowhead indicates a junction between the Kupffer cell and an endothelial cytoplasmic process. $\times 13,000$

FSC. As shown in Figure 13, bundles of collagen fibrils measuring approximately $270-460 \AA$ (on an average $365 \AA$ ) in diameter often occur close to the FSC. They are entwined or arranged in parallel with fuzzy filaments, resembling the material within the dilated cisterns of the RER. These findings are considered to support the assumption that the precollagen elaborated by the RER and stored in the cisterns may be discharged to the cell surface to form fine collagen fibrils, which develop gradually to thicker ones in consequence of further apposition of material discharged into the Disse's space.

The FSC usually extends cytoplasmic processes along the endothelial lining: Some of these are closely apposed to the endothelial sheet to reinforce it (subendothelial processes). In samples prepared for the transmission electron microscopy of the kitten liver, a maximum of five processes have been found in one plane of section to be sent out from one cell body, and some of them show further bifurcations in the distal portion (Fig. 14). Thicker portions of the processes contain sparse mitochondria and cisternae of the RER as well as free polysomes while thinner portions contain only free ribosomes. Microfilaments and microtubules can be demonstrated extending along their long axis (Fig. 15). Isolated segments of the processes of the FSCs are frequently found in random places of the Disse's space along the endothelial sheet, occasionally simulating double-layered endothelial lining (Fig. 1, 10). Sparse short microvillous processes protrude into the 


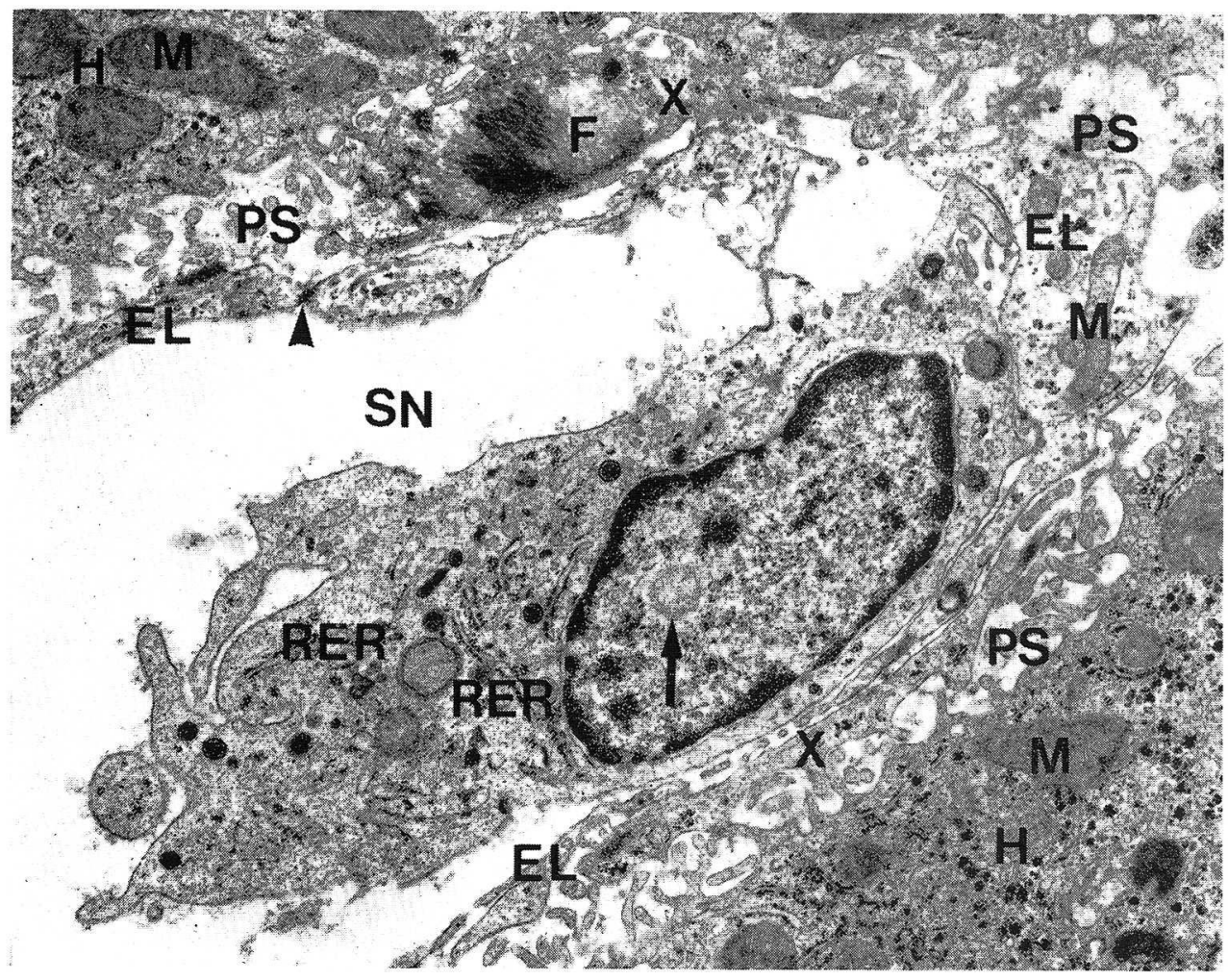

Fig. 10. A Kupffer cell having a large spheridy (nuclear body) surrounded by a light halo in the karyoplasm (arrow). In the cytoplasm many flattened cisternae of the RER and dense bodies of variable sizes are seen. $E L$ endothelial lining of the sinusoid (SN), showing the sieve plates and a junction (arrowhead) between neighboring endothelial cell processes. $F$ bundle of collagen fibrils embraced by a subendothelial process $(X)$ of a FSC, $H$ hepatocytes, $M$ mitochondria, $P S$ perisinusoidal space. $\times 13,500$

Disse's space from the cell body as well as from the thick cytoplasmic processes interlacing with hepatocytic microvilli.

Vesicles and invaginations of the plasma membrane suggesting an micropinocytotic activity of the FSC are sparse.

In the kitten liver, FSC generally contains a small number of lipid droplets, usually surrounded by the dense accumulation of glycogen $\beta$-granules. The glycogen accumulation occurs in indefinite locations of the cytoplasm, even in the thick portion of the cytoplasmic processes (Fig. 1). In contrast to the glycogen granules in the hepatocyte, those in the FSC do not form rossettes ( $\alpha$-granules) for an unknown reason, thus $\alpha$-granules are only exceptionally detected among $\beta$-granules (Fig. 15). In the accumulations of glycogen granules, lipid droplets occur either as electrontransparent vacuoles or moderately electron-opaque droplets according to the degree of dissolution of the lipid content during the specimen preparation, and glycogen granules closely adhere to their surfaces (Fig. 16, 18, 19). There are FSCs which contain the glycogen accumulation but no lipid droplet or vacuole (Fig. 17). Thus, 
"empty FSCs" are not rare. This finding seems to give evidence that the appearance of the glycogen granules precedes that of the lipid droplet. It must further be an important fact that the cisterns of the RER and mitochondria are always located close to the glycogen accumulation. Cisternae of the RER, partially devoid of studded ribosomes, and being accompanied by mitochondria closely surround or penetrate the glycogen accumulation (Fig. 16, 18, 19). In rare cases in which naked lipid droplets occur independently in the cytoplasm, the same intimate positional relationship is also observed between the lipid droplets and the cisternae of the RER accompanied by mitochondria (Fig. 12a).

\section{Other cells in the Disse's space}

In the immature kitten liver the perisinusoidal space often contains plasma cells and macrophages (Fig. 14). The plasma cell is found singly or occasionally in clusters in the Disse's space. In a cluster of plasma cells a macrophage and FSC may be detected. In common, a macrophage is found independently in the Disse's space and agree from every cytological respect with the Kupffer cell. A plasma cell resembles FSC in the richness of the cisterns of the RER, but differs from it in large mitochondria. These two cell types may probably migrate through the fenestrated endothelial lining into the sinusoidal lumen. Plasma cells are occasionally found freely in the sinuoidal lumen, whereas macrophages are revealed on the way of penetrating the endothelial gap (Fig. 20), though they have not been encountered

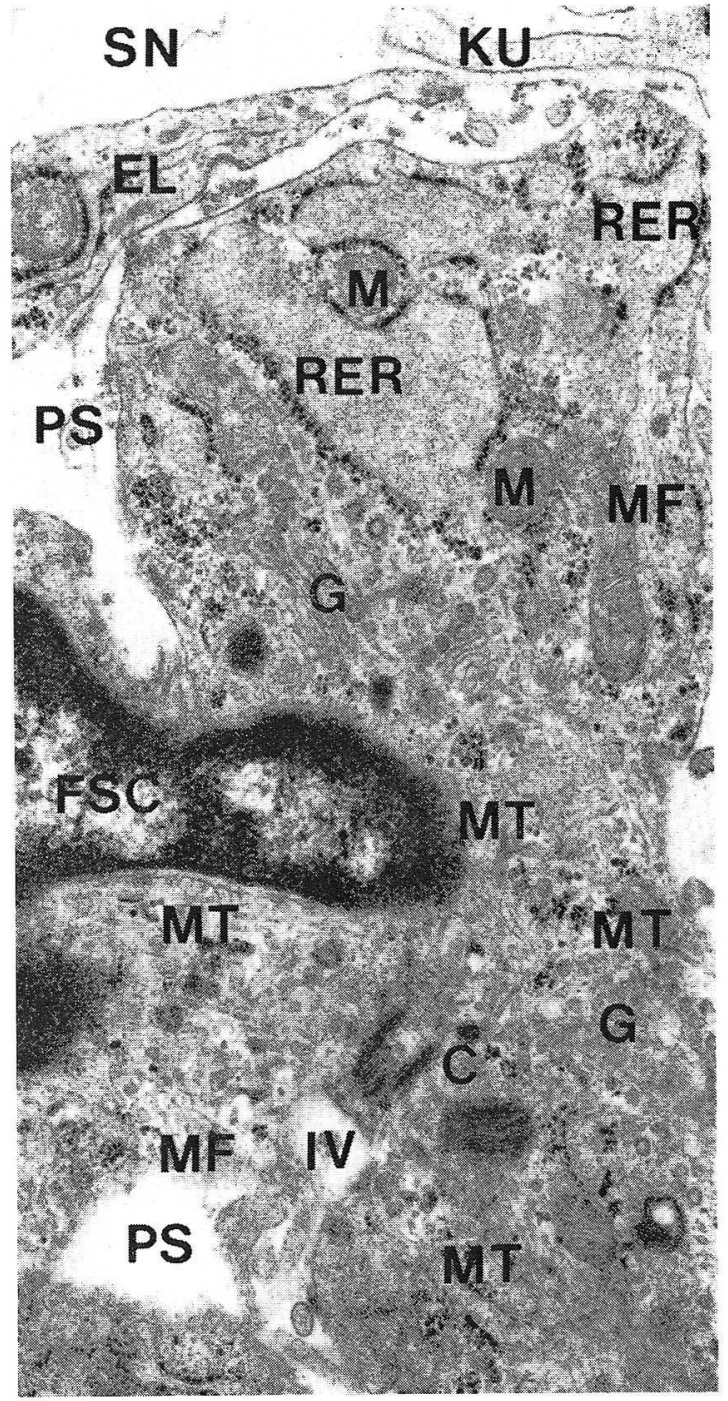

Fig. 11. Nucleated portion of a fat-storing cell (FSC) containing a diplosome $(C)$ within the Golgi complex $(G)$. Microtubules $(M T)$ are converged to the diplosome, abutting on the bottom of an invagination of the plasma membrane $(I V)$. Microfilament $(M F)$ are also seen. Dilated cisternae of the RER are filled with a finely filamentous material and partially devoid of studded ribosomes. EL endothelial lining, $K U$ pseudopod of the Kupffer cell, $M$ mitochondria, PS Disse's space, $S N$ sinusoid. $\times 25,000$ 
floating freely in the sinusoidal lumen.

\section{Collagen fibers}

As already described, cisternae of the RER of the FSCs are more or less strikingly

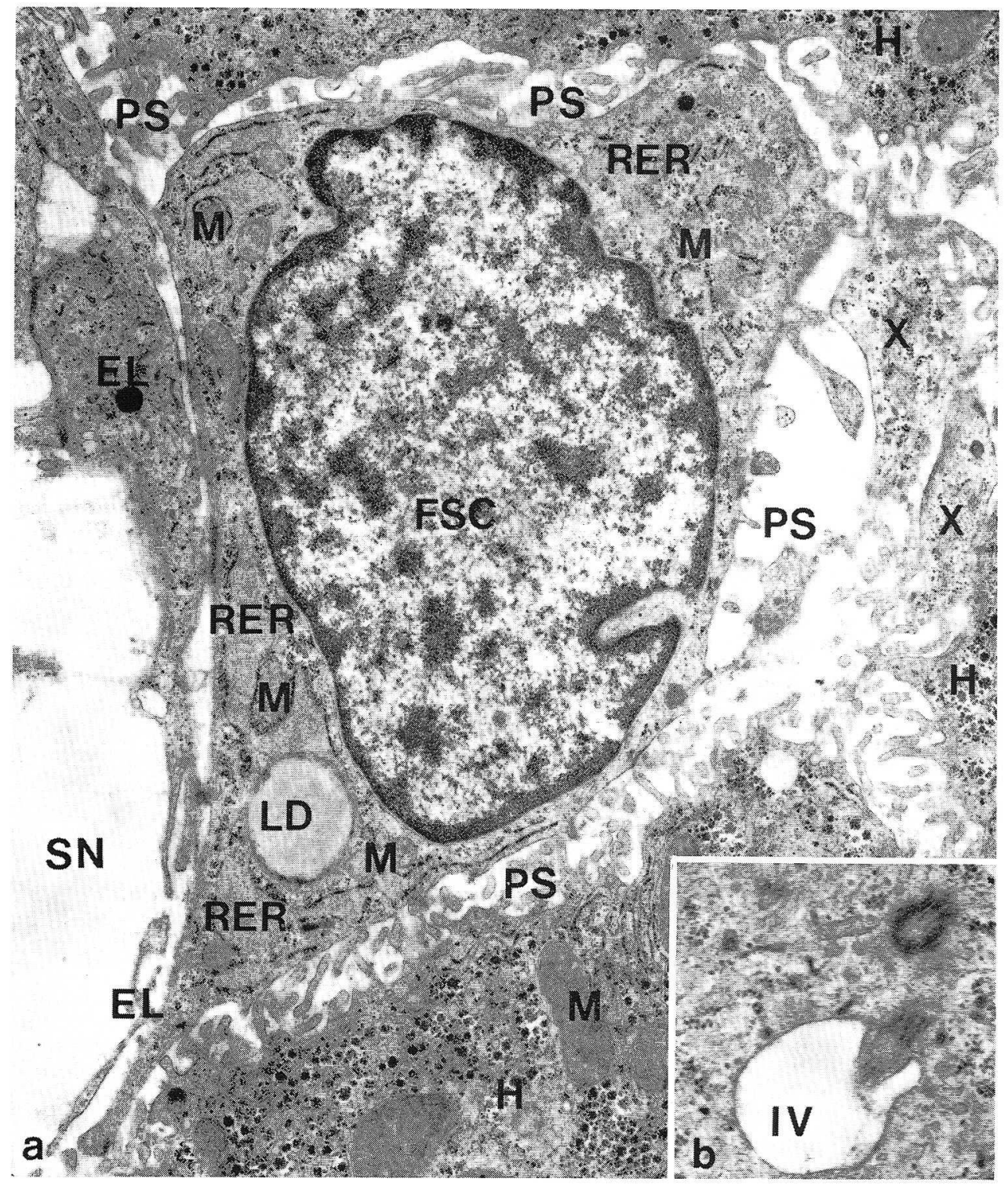

Fig. 12. a. A fat-storing cell $(F S C)$ containing numerous cisternae of the RER and a lipid droplet $(L D)$ devoid of associated glycogen accumulation but surrounded by dilated cisternae of the RER and mitochondria $(M)$. EL endothelial lining, $H$ hepatocytes, $P S$ Disse's space, SN sinusoid, $X$ cytoplasmic processes of the FSC. $\times 13,500 \quad$ b. From one of the paired centrioles of the FSC, a single cilium protrudes into an invagination (IV) of the plasma membrane. $\times 25,000$ 


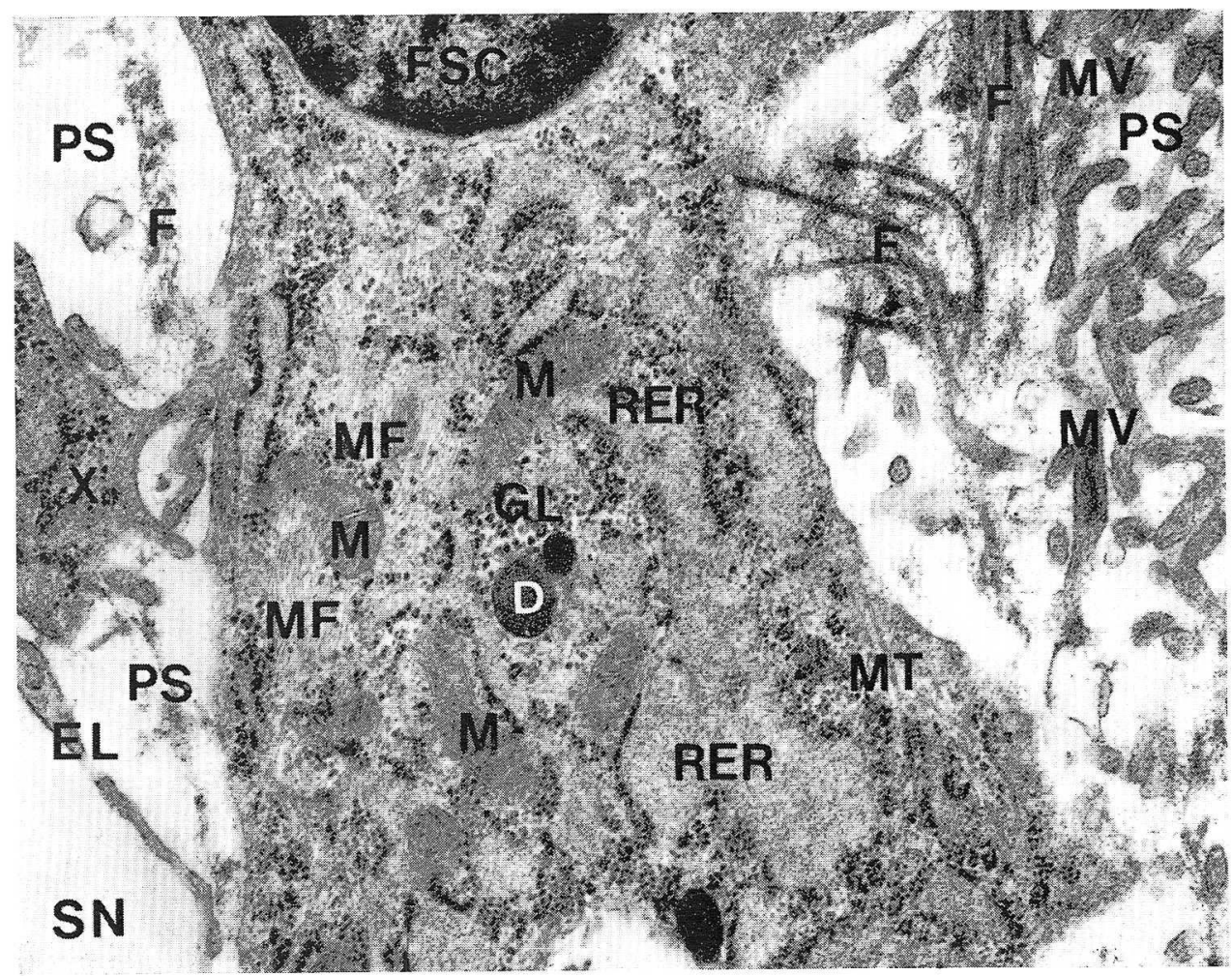

Fig. 13. A nucleated part of a fat-storing cell $(F S C)$ containing numerous dilated cisternae of the RER filled with a finely flocculent material probably precursor of collagen fibrils. On the right side of this FSC loose bundles of collagen fibrils $(F)$ are present and they are entwined or accompanied by fine filaments suggesting further development by apposition of precursor substance derived from the RER. $D$ lysosomes, $E L$ endothelial lining, $G L$ small cluster of glycogen $\beta$-particles, $M F$ microfilaments, $M T$ microtubules, $M V$ microvilli of hepatocytes, $P S$ perisinusoidal space, $S N$ sinusoid, $X$ cytoplasmic process of FSC. $\times 25,000$

dilated and filled with a fine fibrillar or flocculent material, suggesting an active fibrogenesis in the Disse's space. In spite of this, the amount of collagen fibrils in the Disse's space is, in general, not so remarkable. The amount of collagen fibers, however, increases toward the region neighboring the portal canal, where many collagen fibrils occur in the Disse's space and large bundles of thicker collagen fibrils with the diameter of about $500 \AA$ on the average are not rare. Collagen fibrils found in the Disse's space far from the portal canal generally measure $270-460 \AA$ in diameter, form loose bundles of varying thickness and frequently occur in intimate spatial relationship to the FSC (Fig. 8a, 10). However, those in close positional relationship to hepatocytes may be encountered in such locations as the recessus of the interhepatocytic space, where portions of FSCs fail to be demonstrated. 


\section{DISCUSSION}

Hepatocyte: The hepatocyte from an immature kitten was characterized by welldeveloped cisternae of the RER, numerous mitochondria and abundance of glycogen

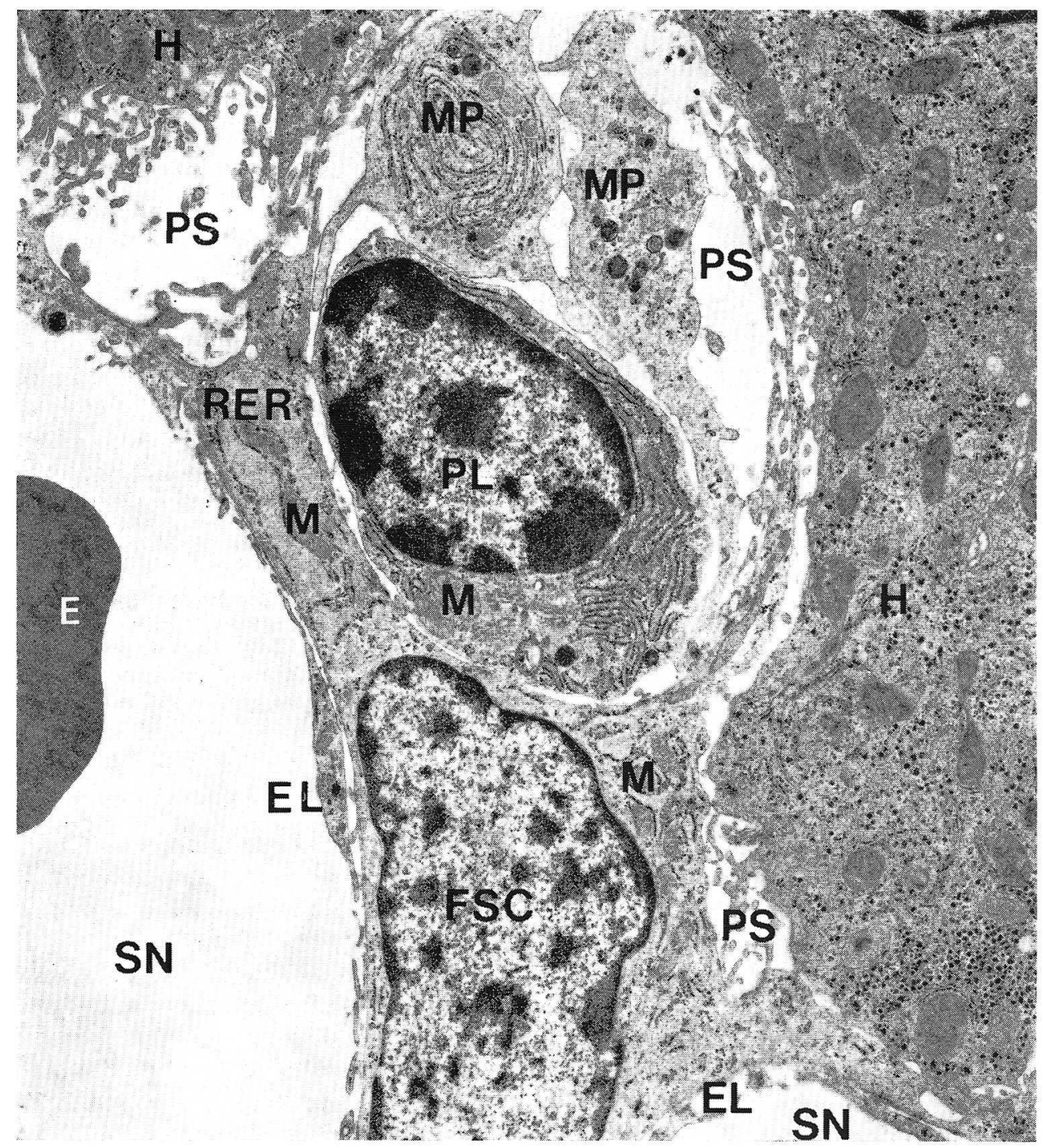

Fig. 14. A fat-storing cell (FSC) sending out five cytoplasmic processes, three of which are shown in this picture. Upper two of them are bifurcated, and between them intervenes a wide perisinusoidal space $(P S)$ which contains a plasma cell $(P L)$ and two macrophages $(M P)$. In the endothelial lining $(E L)$ sieve plates and cytoplasmic processes are distinguished. $E$ erythrocyte, $H$ hepatocyte, $M$ mitochondria, $S N$ sinusoid. $\times 8,600$ 
$\alpha$-particles. Mitochondria and cisternae of the RER showed intimate positional relationships. These ultrastructural findings indicated an advanced morphological differentiation of the hepatocyte. The Golgi complexes show cytological features corresponding to those of fully developed hepatocytes from the mature animals, but the VLDL particles of high electron densities were scarce in the Golgi cisternae and the usual location of the Golgi complexes in the apical cytoplasm near the bile canaliculus seemed to have not yet been established. Dense bodies, probably lysosomes, were notyet concentrated in the pericanalicular areas, nor were large lipofuscin granules identified. In the present study many problems concerning the VLDL particles were not discussed, although many investigators of the hepatocy te had endeavored to elucidate the participation of cell organelles in the synthesis of these particles and to clarify their chemical composition and releasing mechanism of these particles into the Disse's space (Hamil ton et al., 1967; Stein and Stein, 1967; Claude, 1970; MA and BiempicA, 1971; Reid and Hill, 1975). According to a review by Hruban and RechCigL (1969), the hepatic and renal microbodies or peroxisomes in species of carnivore possess the marginal plate and the crystalloid core. In the kitten liver examined in the present study microbodies were roughly round in shape and possessed both the marginal plate and the crystalloid core. Measuring 0.4$0.7 \mu \mathrm{m}$ in diameter, they were as large as those reported by MA and BiEMPICA (1971) in human livers.

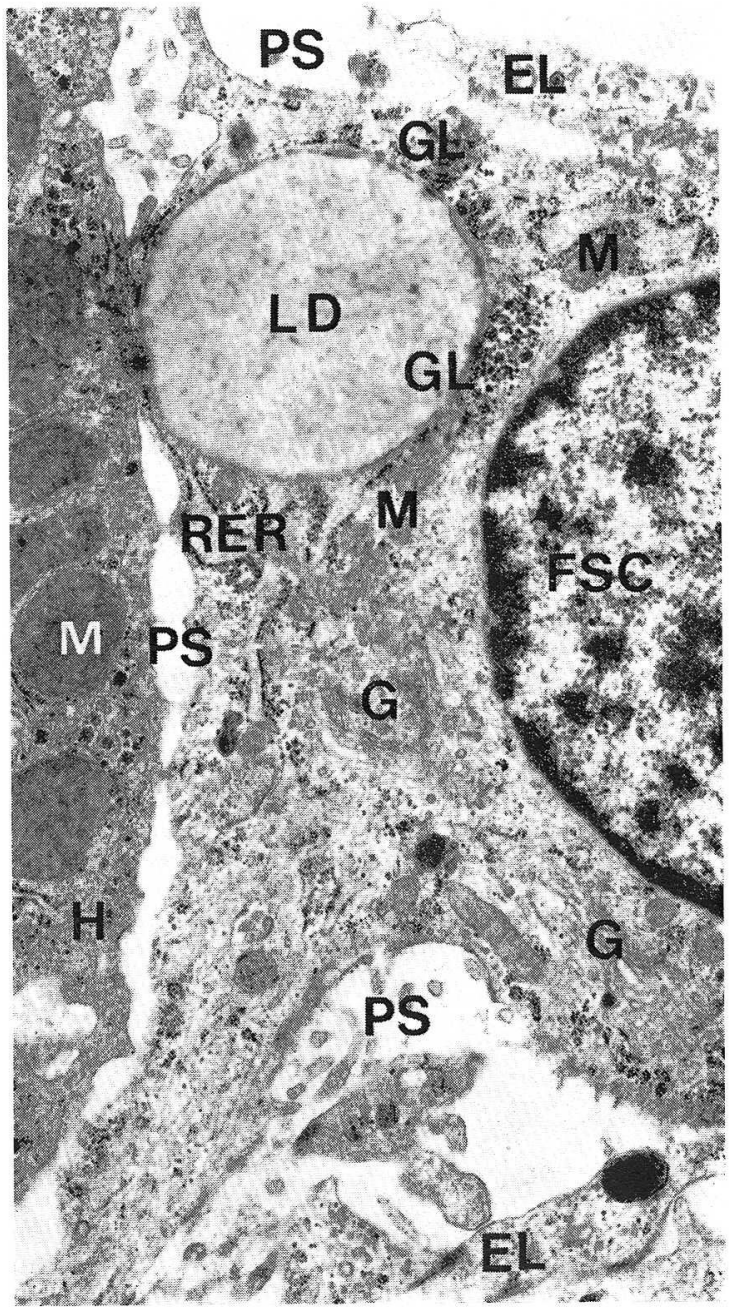

Fig. 15. A nucleated portion of a fat-storing cell (FSC). On one side of the nucleus, are seen large Golgi complexes $(G)$ and a relatively large lipid droplet $(L D)$, the latter being surrounded by a small accumulation of glycogen particles $(G L)$, cisternae of the RER and mitochondria $(M)$. In the cytoplasmic process extending toward the bottom left corner numerous microfilaments and microtubules are visible. EL endothelial lining, $H$ hepatocyte, $P S$ perisinusoidal space. $\times 15,000$ 


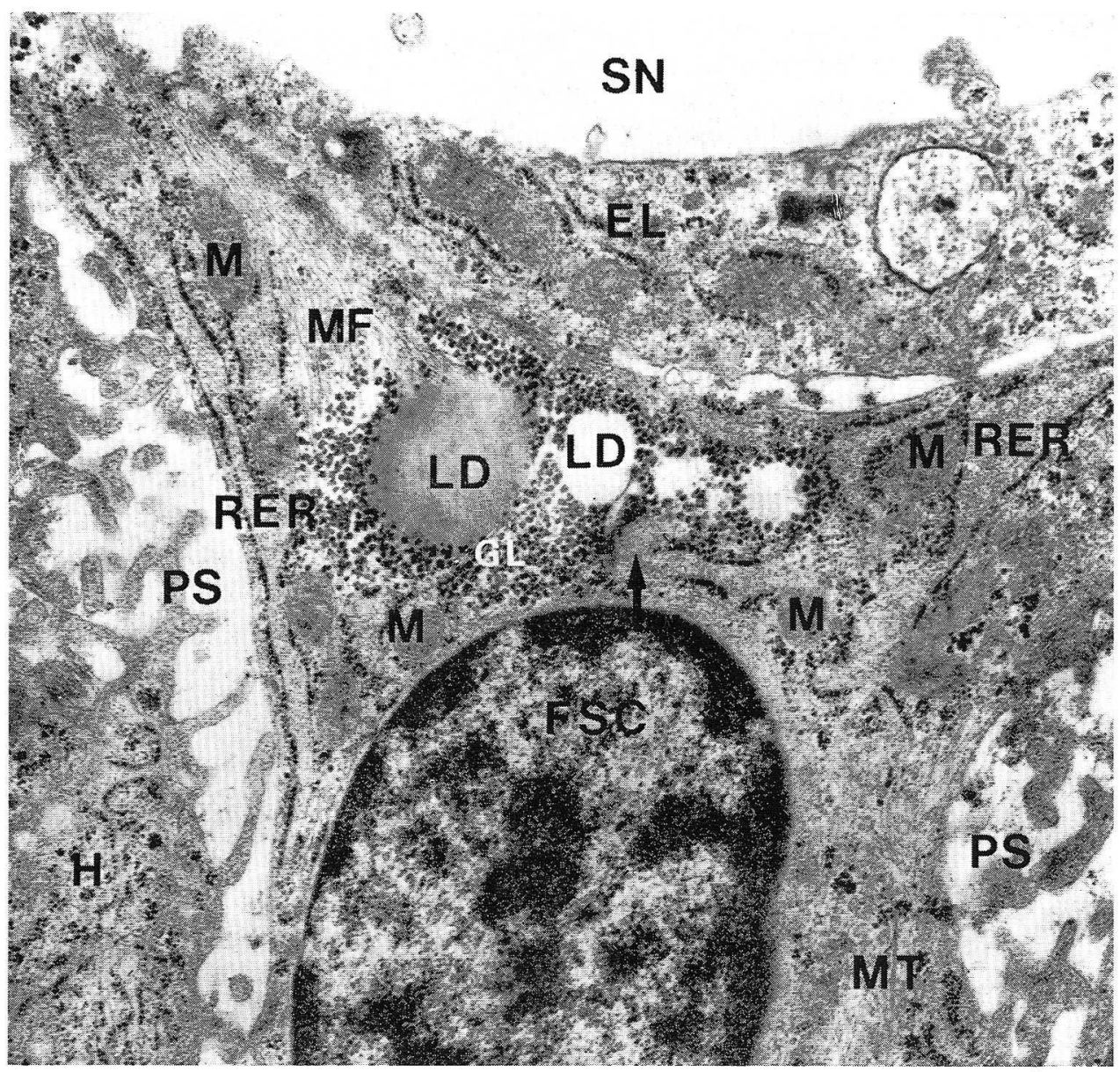

Fig. 16. A nucleated portion of a fat-storing cell (FSC). On the upper pole of the nucleus, an accumulation of glycogen $\beta$-particles $(G L)$ is present, in which four lipid droplets or vacuoles $(L D)$ appear surrounded by glycogen accumulation. Several mitochondria $(M)$ and dilated cisternae of the RER enclose the above inclusion complex. Some extensions (arrow) of the cisternae of the RER penetrate into the glycogen accumulation with their studded ribosomes being lost. $E L$ endothelial lining, $H$ hepatocyte, $M F$ microfilaments, $M T$ microtubule, $P S$ Disse's space, $S N$ sinusoid. $\quad \times 23,500$

In contrast to the findings obtained by the above authors in bioptic study on human livers, cisternae of the SER of the kitten liver were completely missed in accumulations of glycogen particles. The tubular cisternae of the SER were revealed only in those areas around the mitochondria and microbodies where sparse glycogen particles were loosely distributed. Especially around the microbodies, the tubular cisternae were closely applied along their single membranes. However, a continuity of the tubular SER and the limiting membrane of the microbody as proposed by $\mathrm{MA}_{\mathrm{A}}$ and BiEmpicA, was not confirmed. The intimate spatial relationship between the glycogen $\alpha$-particles and the microbodies was repeatedly demonstrated in the peripheral part of the dense glycogen accumulations. The above positional relation- 
ship of microbodies with SER and glycogen particles might support the assumption that microbodies may be responsible for the gluconeogenesis as proposed by MA and BiempicA, although on the other hand Yoshinara (1979), who also observed the continuity between microbody and ER, has proposed that the hepatocytic microbody would participate in the metabolism of lipid of endocytosed chylomicra. Also Fanim et al. (1976) have suggested in the fatstoring cell of the rat that microbodies participate in the fat metabolism. In the kitten hepatocytes, however, no evidence was obtained which might support the metabolic relationship between the lipid droplet and the microbody.

Sinusoidal endothelium: According to Naito and Wisse (1977), hepatic sinusoidal endothelial cells in the fetal rat liver at 15-20 days of gestation had a limited number of fenestrations, while the corresponding cells of the 67-day old kitten are already fully differentiated as comparable to those of the adult. The membranous cytoplasmic extentions were divided into the thicker "cytoplasmic processes" and the thinner "sieve plates" provided with grouped fenestrae measuring on the average $1,300 \AA$ in diameter. The

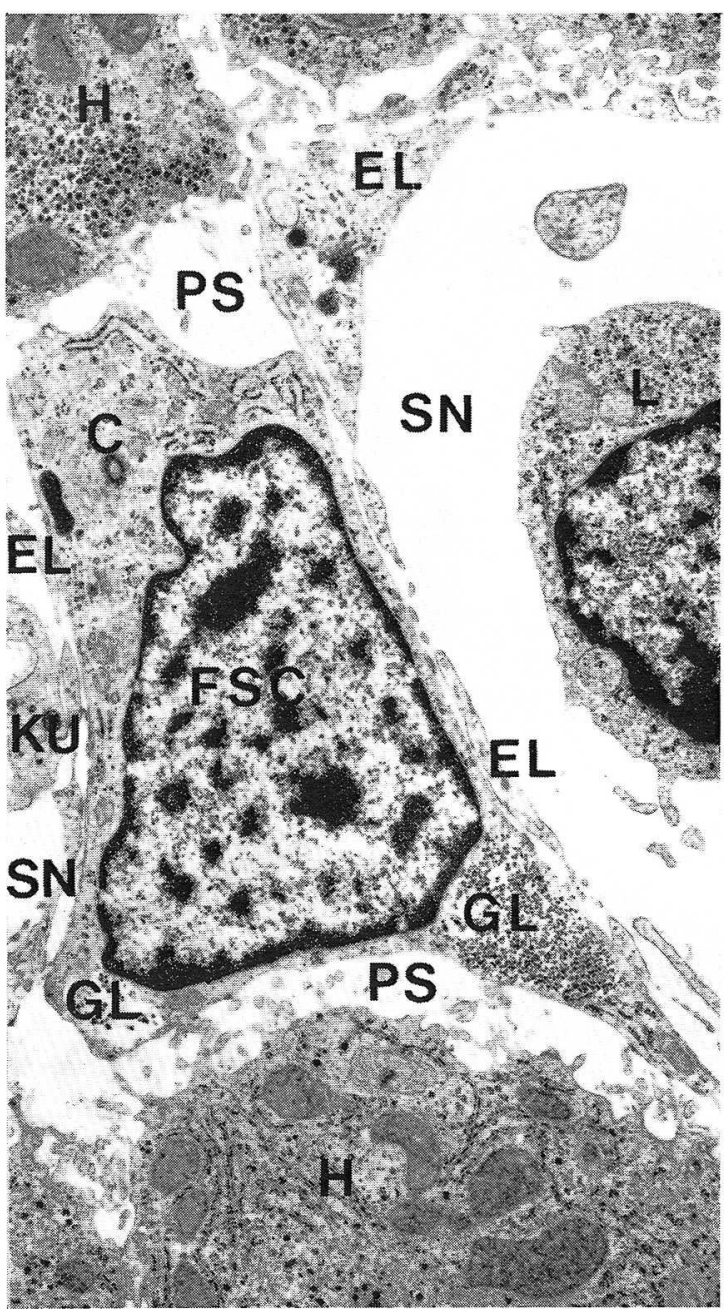

Fig. 17. A fat-storing cell (FSC) which is devoid of lipid droplets but which contains glycogen accumulations $(G L)$. C centriole, $E L$ endothelial lining, $H$ hepatocyte, $K U$ Kupffer cell, $L$ lymphocyte, $P S$ perisinusoidal space, $S N$ sinusoid. $\times 8,600$ sinusoidal endothelial cell of the kitten possessed numerous, large lysosomes, phagosome-like vacuoles and smooth membrane-bound tubules containing electron-dense materials, suggesting an active phagocytic activity.

Kupffer cell: In rabbit (YAmAGISHI, 1958) and rat (NAito and WisSE, 1977) fetuses already from the 15 th gestation day, the Kupffer cell has been reported to phagocytose erythroblasts and their extruded nuclei. Also in human fetuses, Kupffer cells proliferated from the third month of gestation and showed vigorous phagocytic activity to erythroblasts, some ingesting two or more of them (TAHIRA, 1958). Such 
erythrophagocytic activity, however, was reduced toward the later stages of gestation and neonatal stages to become comparable to that in the adult. The Kupffer cells of the immature kitten lying on, or incorporated in the endothelial lining and sometimes fixed by the so-called "junctional complex" (WISse, 1970) to the cytoplasmic processes of the endothelium, exhibited vigorous phagocytic activity to mature ery-

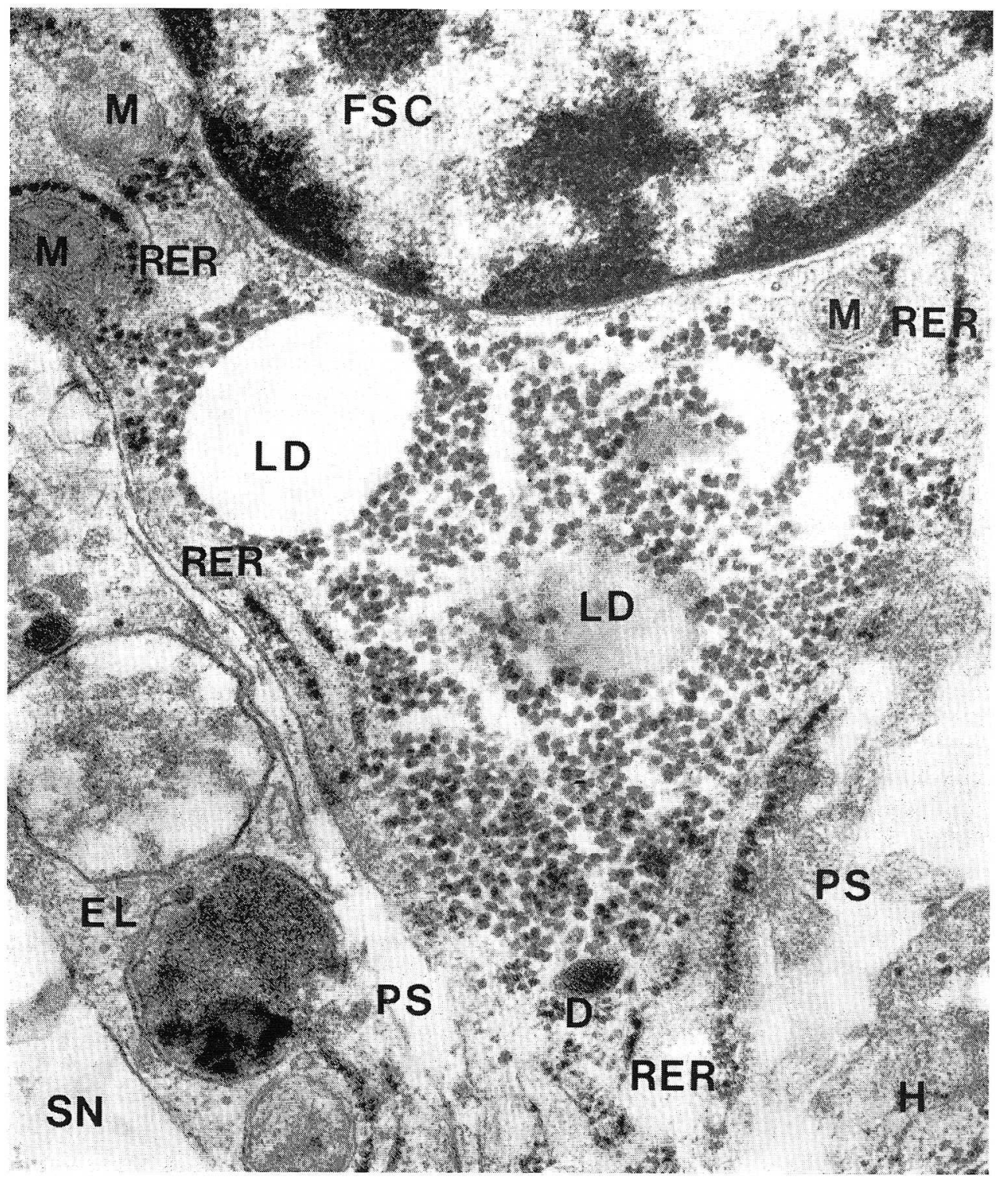

Fig. 18. A nucleated portion of a fat-storing cell (FSC). Lipid droplets or vacuoles $(L D)$ appear in the accumulation of glycogen $\beta$-particles $(G L)$. This inclusion complex is enclosed by a number of mitochondria and cisternae of the RER. The surfaces of the cisternae of the RER devoid of attached ribosomes directly face the glycogen accumulation. $D$ lysosome, $E L$ endothelial lining, $H$ hepatocyte, $P S$ perisinusoidal space, $S N$ sinusoid. $\times 50,000$ 


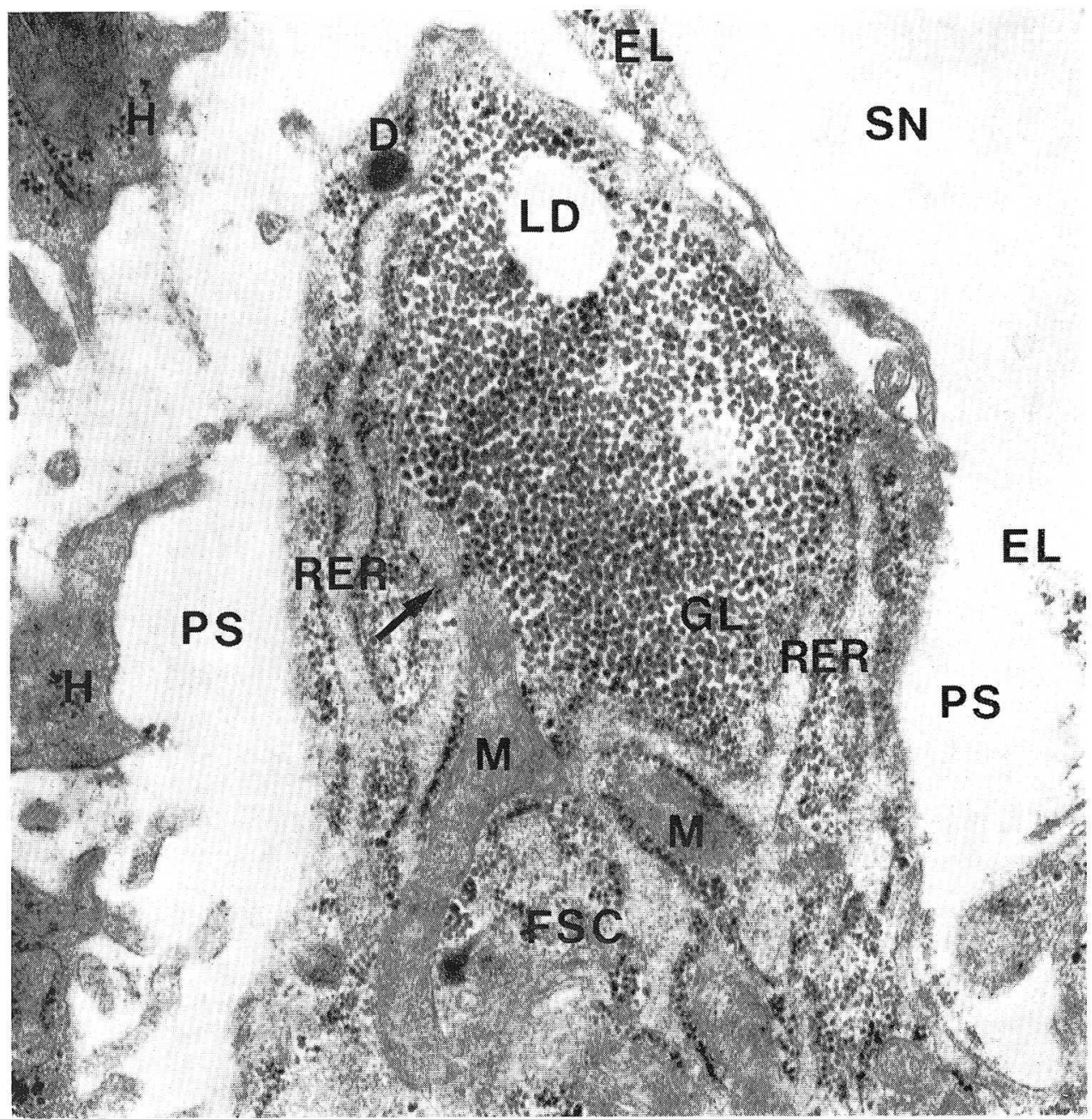

Fig. 19. A portion of a fat-storing cell (FSC) containing a dense accumulation of glycogen $\beta$-particles $(G L)$ in which a small lipid vacuole $(L D)$ appears. Intimate spatial relationship is observed between the inclusion complex and cisternae of the RER as well as mitochondria $(M)$. An extension of the cisterna of the RER devoid of attached ribosomes penetrates into the glycogen accumulation (arrow). D lysosome, $E L$ endothelial lining, $H$ hepatocyte, PS Disse's space, $S N$ sinusoid. $\times 33,200$

throcytes, granulocytes and blood platelets. Thus, the phagocytic activity of the Kupffer cell of the 67-day old kitten may be comparable to that of the Kupffer cells from fetal liver in humans and some animals.

Apart from the vigorous phagocytic activity, the Kupffer cells of the kitten showed the same morphological characteristics as in adult livers. In the preparations prefixed by perfusion fixation with glutaraldehyde, the fuzzy coat covering the entire surface of the plasma membrane was unsatisfactorily preserved. Short segments of the so-called worm-like bodies, characterized by the median dense line as in rodent 


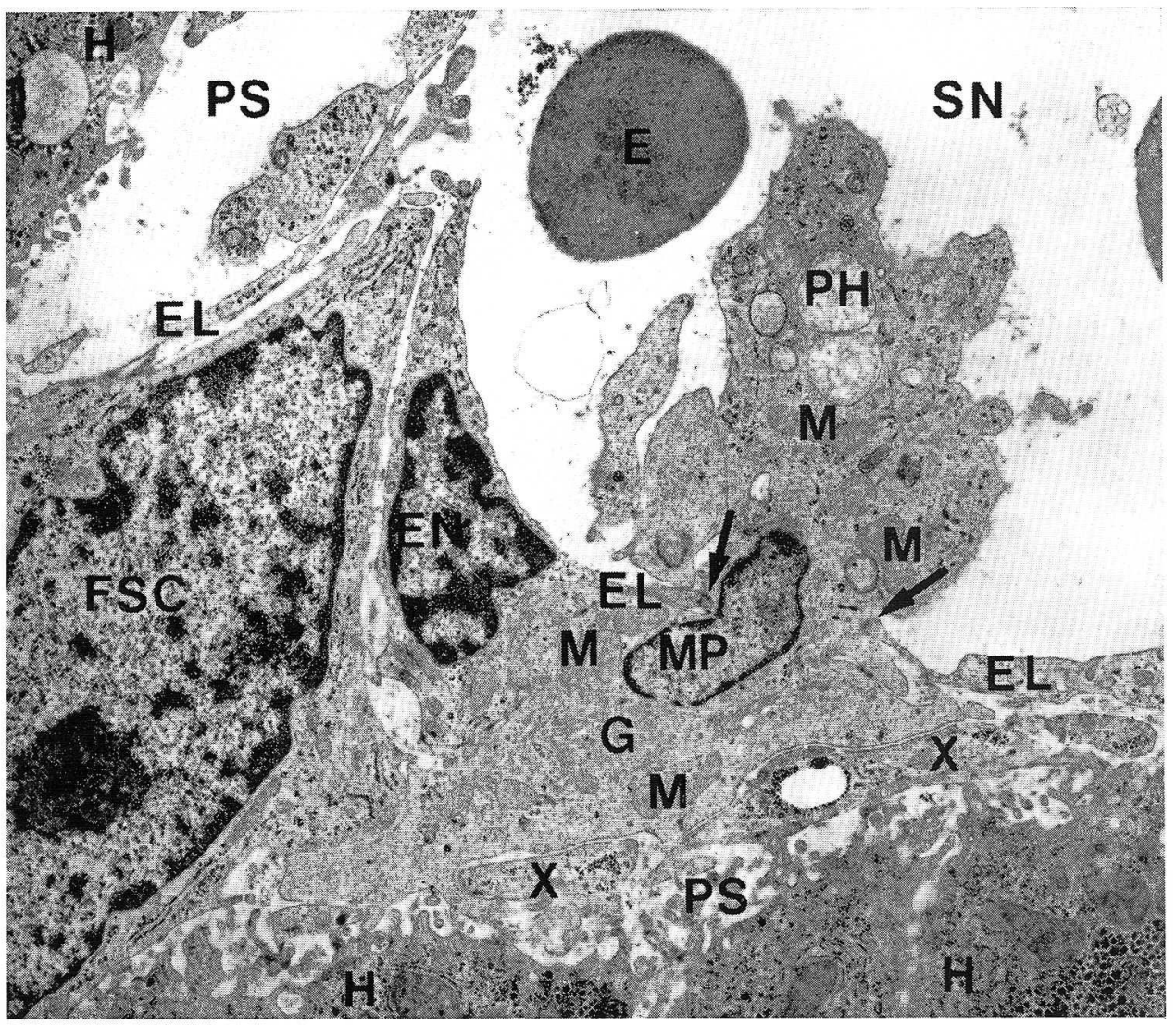

Fig. 20. A macrophage $(M P)$ migrating from perisinusoidal space $(P S)$ toward the sinusoid ( $S N)$ through a gap in the endothelial lining $(E L)$ limited between two arrows (junctions). $E N$ perikaryon of the endothelial cell, $E$ erythrocyte, $G$ Golgi complex, $H$ hepatocyte, $M$ mitochondria, $P H$ phagosome, $X$ cytoplasmic processes of the fat-storing cell (FSC). $\times 8,600$

Kupffer cell, were occasionally revealed in the cytoplasm suggesting the origin of this structure from indentations of the plasma membrane. The worm-like bodies, or micropinocytosis vermiformis, have been revealed in Kupffer cells of the liver and macrophages of other organs of the rodents but recently they were demonstrated by Tanuma (1978) in the Kupffer cells of the bat. From the present findings it is expected that more complete and complicated profiles of the worm-like bodies may be demonstrated also in the cat Kupffer cells by further careful searching.

In the nuclei of the three cell types of the hepatic sinusoidal wall, the spheridy or the nuclear body has often been demonstrated. Its nature and functional significance, however, are unknown. The frequency of its occurrence has been proved to be highest in the Kupffar cell nucleus.

Fat-storing cell: The FSC of the 67-day old kitten exhibited ultrastructural characteristics comparable to those of the adult; they showed a low cytoplasm/nuclear ratio, were devoid of the basal lamina and contained numerous cisternae of the RER. 
From the distal centriole of the diplosome present within the well-developed Golgi complex, a single cilium probably sensory in nature protruded into the Disse's space through a deep invagination of the plasma membrane. This structure agrees with what has been reported on the FSC of the human (Ito and Shibasaki, 1968), bat (TAnuma and Ito, 1978) and crucian liver (Tanuma and Ito, 1980). It is presumed that the single cilium might be a common metaplasmic structure of the FSC.

The richness in microfilaments and microtubules might speak on one hand for the supportive or mechanical function of the FSC including its cytoplasmic processes.

The most conspiquous features of the FSC of the immature kitten liver is that they possessed a small number of small lipid droplets within the accumulation of glycogen $\beta$-granules. The evidence that in immature mammals the FSC contains smaller amounts of lipid droplets than in the adults has been given by YAMAGISHI (1958) in various developmental stages of rabbits. In human fetuses, Yамамото (1975), ENZAN and KAWAKAMI (1978) and ENZAN and Yамамото (1980) revealed that the FSC contained sparse small lipid droplets surrounded by glycogen granules. Recently, Usuku et al. (1980) have obtained the same finding in the developing preadipocyte of neonatal rat. However, the presumption that this intimate relationship between lipid droplets and glycogen particles might be confined to the FSC of immature and fetal animals would be questionable, since it has already been proved by light microscopic histochemistry that in human adults and mature rabbits the FSC commonly contained glycogen in considerable amounts between the lipid droplets (Ito et al., 1953; Tsunoda, 1955). Possible correlation between fat synthesis and glycogen granules in the FSC has already been discussed with reference to that in fat cells (ITO, 1969; 1978). In their handbook review dealing with glycogen metaconversion of carbohydrates into fat. They further pointed out that the levels of bolism in adipose tissue, SHAFriR et al. (1965) stated that glycogen deposition preceded fat accumulation, and that glycogen may be a transitional compound in the glycogen in adipose tissue were in good correlation with the rates of fatty acid synthesis and esterification. Shapiro (1965) introduced in his review the assertion that glucose is used both for fatty acid synthesis and for formation of the glycerol moiety of glycerides. These views seem to support the involvement of the carbohydrates in fat synthesis in the adipocytes and the possibility that the same would also be the case in the FSC. However, Napolitano (1965) commented that no authors have been able to point out any cell organelles as being directly concerned with either lipogenesis or lipolysis in adipocytes. In the present study we could confirm in no instances that lipid droplets and glycogen particles are in an intimate positional relation with the Golgi complex. At a glance of the electron micrographs of the FSCs of the 67-day-old kitten, the picture of glycogen particles adhering on the border of the lipid droplets appears to simulate the direct conversion of glycogen particles into lipid as proposed by Gieseking (1961)and Müller (1969) in their electron microscopic studies on fat cells. However, it was evidenced that cisternae of the RER which were partially devoid of studded ribosomes and a number of mitochondria were always revealed around the lipid droplets, either surrounding or penetrating the glycogen accumulation. The same figures were confirmed also around the lipid droplet accompanied by no glycogen accumulation. These findings seem to support that cisternae of the RER and mitochondria might be responsible for lipid synthesis. MA and BIEMPICA (1971) proposed that mitochondria, apart from be- 
ing an energy source, possess enzymes that are, with microsomal enzymes, involved in the formation of triglyceride from fatty acids. According to MA and BIEMPICA (1971), peroxisomes (microbodies) might play a role in gluconeogenesis in hepatocytes. Recently, FAHimi et al. (1976) demonstrated peroxisomes by means of the cytochemical method in the three types of sinusoidal cells of the rat liver, and in the FSC they presumed the participation of peroxisomes in the lipid metabolism. In the present study, however, we could not reveal these organelles anywhere in the FSC of the kitten liver.

The second noteworthy feature of the FSCs of the kitten liver was striking dilation of abundant cisternae of the RER distributed throughout the cytoplasm including cytoplasmic processes; the cisternae were filled with finely flocculent material of moderate electron density, suggesting the active production of collagen precursor. Against expectation, however, the amounts of collagen fibers in the Disse's space were not large, although there was a tendency for the collagen fibrils toward the portal area to increase, making thicker bundles. The collagen fibers in the Disse's space were in an intimate positional relation to the FSC, although occasional fibers apparently related only with hepatocytes were recognized especially in the interhepatocytic recessus. Recently, NAGAI and his co-workers have presented the opinion that hepatocytes themselves also might participate in fibrogenesis in the Disse's space (Ohuchi and Tsurufuji, 1972; Sakakibara et al., 1978; Hata et al., $1978,1979)$. This new proposal should require detailed re-examination from the morphological viewpoint.

Other cells in Disse's space: In the Disse's space of 67-day old kitten, plasma cells and macrophages were identified, the former occurring also in the sinusoidal lumen. In fetal and neonatal rats NAITO and WissE (1977) revealed occasional macrophages in the Disse's space. In adult bats, TAnuma and ITo (1978) found occasional lymphocytes and macrophages resembling in ultrastructure the Kupffer cell in the Disse's space: they demonstrated a considerable number of plasma cells in the Disse's space and the sinusoid. In the Disse's space of the adult rabbit TAMARU (1979) rarely encountered a macrophage exhibiting the same ultrastructure as the Kupffer cell. The so-called "microfilament-rich perisinusoidal cells" newly observed by NopANITAYA et al. (1979a, b) in the Disse's space of fresh water and marine teleosts may be nothing but the empty fat-storing cells. To sum up, the most common cell types in the Disse's space other than the three types of sinusoidal cells are plasma cells and macrophages. The plasma cells, whose accumulation was found in the Disse's space in the present study, must be involved in an immune reaction of the liver by producing $\gamma$-globulin. The macrophages with the same ultrastructure as the Kupffer cells were found in the Disse's space or on the way of migration to the sinusoid, as in the bat liver; they were never found free in the sinusoid. The above findings might support the view of NAITO and WISSE (1977) that the macrophages present in the Disse's space would migrate through the gaps of the endothelial lining toward the sinusoid and might be incorporated in the endothelial lining by being anchored by means of the so-called "junctional complexes" to the latter, to function there as typical Kupffer cells. 


\section{子ネコの肝臓実質, とくに脂肪摄取細胞の電子顕微鏡的研究}

\section{田沼 裕，大畑まさ子，伊東俊夫}

生後 67 日の䧳の子ネコの肝臓実質の形態学的分化を 電子顕微鏡で観察した.

1）肝細胞の分化は進んでいるが，ゴルジ装置の 毛細胆管を囲み 細胞先端部を占める 位置はまだ確立されていない. 多数のミトコンドリアに混じて, 周板と結晶状芯をもつ球 形のマイクロボディが多く存在する，管状の SER はマイクロボディ周囲に見出され，グ リコゲン $\alpha$ 粒子の集積部には証明されない，2）類洞内皮細胞は十分に分化し：“細胞質

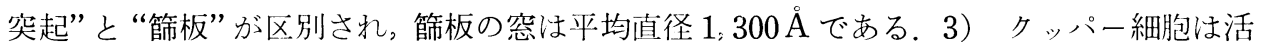
発な血球食食を示す。細胞表面を包むfuzzy coat は十分に保存されていない，細胞質内 に虫様構造の一部が証明された。 4) 個々の脂肪摂取細胞（FSC）の脂肪滴の量は少ない が，大部分はグリコダン $\beta$ 粒子の集積部に現われる．脂肪滴をもたない空虚な FSCにも グリコゲンの集積がある．脂肪滴を囲むグリコゲン集積は RER の小胞やミトコンドリア と密接な位置的関係を示す。グリコゲン， RER，ミトコンドリアの 脂肪合成への関与が 示唆される. 多くの FSC において, 多数の RER の小胞は拡大し, 綿毛状物質で充満し, 膠原線維の前駆物質の合成を示唆する．FSC は多量のマイクロフィラメントと微細管を もち，単一線毛がゴルジ装置内にある双中心子の一方からディッセ腔に出る．5）子ネコ のディッセ腔には FSC のほかに 形質細胞と大食細胞が出現し，後者はクッパー細胞と 超微構造が一致し，類洞内皮層の中に組込まれて クッパー細胞に移行するものと思われ る.

\section{REFERENCES}

Claude, A.: Growth and differentiation of cytoplasmic membranes in the course of lipoprotein granule synthesis in the hepatic cell. 1. Elaboration of elements of the Golgi complex. J. Cell Biol. 47: 745-766 (1970).

Enzan, H. and M. Kawakami : Morphological studies on the hepatic hematopoiesis of human fetuses. Acta haematol. jap. 41: 1214-1230 (1978).

Enzan, H. and M. Yamamoto: Vitamin A-storing cell-general considerations (Japanese text). Cell (Tokyo) 12: 168-175 (1980).

Fahimi, H. D., B. A. Gray and V. K. Herzog : Cytochemical localization of catalase and peroxidase in sinusoidal cells of rat liver. Lab. Invest. 34: 192-201 (1976).

Gieseking, R.: Der Stoff wechsel des braunen Fettgewebes im elektronenmikroskopischen Bild. Beitr. pathol. Anat. 125: 457-475 (1961).

Hamilton, R. L., D. M. Regen, M. E. Gray and V. S. LeQuire: Lipid transport in liver. I. Electron microscopic identification of very low density lipoproteins in perfused rat liver. Lab. Invest. 16: 305-319 (1967).

Hata, R., Y. Ninomiya, Y. Nagai, K. Sakakibara and Y. Tsukada: Active synthesis of collagen by albumin-producing liver parenchymal cell clones in culture. Proc. Jap. Acad. 54, Ser. B.: 391-396 (1978). 
Hata, R., Y. Ninomiya, Y. Nagai and Y. Tsukada: Collagen production by rat liver parenchymal cells in primary culture. Proc. Jap. Acad. 55, Ser. B.: 531-536 (1979).

Hruban, Z. and M. Rechcigl, Jr.: Microbodies and related particles. Morphology, biochemistry, and physiology. Int. Rev. Cytol. (Suppl. 1.): 1-296 (1969).

Ito, T.: Fine structure of the sinusoidal wall of the liver-a review. (Japanese text). Kitakanto Igaku 19: 429-474 (1969).

-: Structure and function of the fat-storing cell (FSC) in the liver-a review. (Japanese text with English abstrract). Acta anat. nippon. 53: 393-422 (1978).

Ito, T. and S. Shibasaki : Electron microscopic study on the hepatic sinusoidal wall and the fatstoring cells in the normal human liver. Arch. histol. jap. 29: 137-192 (1968).

Ito, T., R. Tahira and K. Tsunoda: Über das Vorkommen des Glykogens in den Fettspeicherungszellen (fat-storing cells) der normalen Kaninchenleber. (Japanese text with German abstract). Arch. histol. jap. 5: 541-553 (1953).

Ma, M. H. and L. Biempica : The normal human liver cell. Amer. J. Pathol. 62: 353-376 (1971).

Müller, H.: Feinstruktur in Lipidbildung der Fettzellen in Perimeningealgewebe von Neunaugen unter normalen und experimentellen Bedingungen. Z. Zellforsch. 84: 585-608 (1968).

Naito, M. and E. Wisse: Observations on the fine structure and cytochemistry of sinusoidal cells in fetal and neonatal rat liver. In: (ed. by) E. Wisse and D.L. Knook: Kupffer cell and other liver sinusoidal cells. Elsevier/North-Holland Biomedical Press, Amsterdam, 1977 (p. 497-505).

Napolitano, L.: The fine structure of adipose tissues. In: Handbook of physiology. Sect. 5: Adipose tissue. Amer. Physiol. Soc., Washington, D. C., 1965 (p. 109-123).

Nopanitaya, W., J. L. Carson, J. W. Grisham and J. G. Aghajanian: New observation on the fine structure of the liver in goldfish (Carassius auratus). Cell Tiss. Res. 196: 249-261 (1979a).

Nopanitaya, W., J. Aghajanian, J. W. Grisham and J. L. Carson: An ultrastructural study on a new type of hepatic perisinusoidal cell in fish. Cell Tiss. Res. 198: 35-42 (1979b).

Ohuchi, K. and S. Tsurufuji : Protocollagen proline hydroxylase in isolated rat liver cells. Biochim. biophys. Acta 258: 731-740 (1972).

Reid, I. M. and G. A. Hall : An ultrastructural and biochemical study of hexachlorophane-induced fatty liver in sheep. J. Pathol. 115: 33-43 (1975).

Sakakibara, K., T. Takaoka, H. Katsuta, M. Umeda and Y. Tsukada : Collagen fiber formation as a common property of epithelial liver cell lines in culture. Exp. Cell Res. 111: 6371 (1978).

Shafrir, E., B. Shapiro and E. Wertheimer: Glycogen metabolism in adipose tissue. In: Handbook of physiology. Sect. 5: Adipose tissue. Amer. Physiol. Soc., Washington, D. C., 1965 (p. 313-318).

Shapiro, B.: Triglyceride metabolism. In: Handbook of physiology. Sect. 5: Adipose tissue, Amer. Physiol. Soc., Washington, D. C., 1965 (p. 217-223).

Stein, O. and Y. Stein : Lipid synthesis, intracellular transport, storage and secretion. I. Electron microscopic radioautographic study of liver after injection of tritiated palmitate or glycerol in fasted and ethanol-treated rats. J. Cell Biol. 33: 319-339 (1967).

Tahira, R.: Histogenetische Untersuchungen über die Leber bei Menschenfeten mit besonderer Berücksichtigung der Fettspeicherungszellen (fat-storing cells). (Japanese text with German abstract). Arch. histol. jap. 14: 495-544 (1968).

Tamaru, T.: Electron microscopic studies of Kupffer stellate cells. (Japanese text with English abstract). Med. J. Hiroshima Univ. 27: 235-270 (1979).

Tanuma, Y.: Fine structure of the Kupffer cell in the bat, with special reference to the wormlike bodies. Arch. histol. jap. 41: 113-127 (1978).

Tanuma, Y. and T. Ito: Electron microscope study on the hepatic sinusoidal wall and fat-storing cell in the bat. Arch. histol. jap. 41: 1-39 (1978).

Electron microscopic study on the sinusoidal wall of the liver of the crucian, 
Carrasius carassius, with special remarks on the fat-storing cell (FSC). Arch. histol. jap. 43: 241-263 (1980).

Tsunoda, K.: Über das Vorkommen des Glykogens in den Fettspeicherungszellen (fat-storing cells) der menschlichen Leber. (Japanese text with German abstract). Arch. histol. jap. 7: 565-572 (1955).

Usuku, G., K. Iyama, K. Osono and C. Araki : Genesis and growth of fat cells, and their abnormalities. (Japanese text). Cell (Tokyo) 12: 638-647 (1980).

Wisse, E.: An electron microscopic study of the fenestrated endothelial lining of rat liver sinusoids. J. Ultrastr. Res. 31: 125-150 (1970).

: An ultrastructural characterization of the endothelial cell in the rat liver sinusoid under normal and various experimental conditions, as a contribution to the distinction between endothelial and Kupffer cells. J. Ultrastr. Res. 38: 528-562 (1972).

Yamagishi, M.: Untersuchungen über die embryonale und postnatale Histogenese der Kaninchenleber mit besonderer Berücksichtigung der Entwicklung der Fettspeicherungszellen (fat-storing cells). (Japanese text with German abstract). Arch. histol. jap. 15: 25-68 (1958).

Yamamoto, M.: Ultrastructure and function of Ito cell (fat-storing cell) in the liver. (Japanese text with English abstract). Med. J. Hiroshima Univ. 23: 245-274 (1975).

Yoshihara, R.: Variation of the endoplasmic reticulum in rat hepatocyte. (Japanese text). Ochanomizu Med. J. 27: 53-74 (1979).

田沼裕

于173 東京都板橋区加賀2-11-1

帝京大学医学部

第一解剖学教窒
Dr. Yutaka TAnuma

Department of Anatomy

Teikyo University School of Medicine

Kaga 2-11-1, Itabashi-ku

Tokyo, 173 Japan 